\title{
A Functional Null Mutation of SCN1B in a Patient with Dravet Syndrome
}

\author{
Gustavo A. Patino, ${ }^{1,3}$ Lieve R. F. Claes, ${ }^{4,5,6}$ Luis F. Lopez-Santiago, ${ }^{1}$ Emily A. Slat, ${ }^{1}$ Raja S. R. Dondeti, ${ }^{1}$ Chunling Chen, ${ }^{1}$ \\ Heather A. 0'Malley, ${ }^{2}$ Charles B. B. Gray, ${ }^{1}$ Haruko Miyazaki, ${ }^{8}$ Nobuyuki Nukina, ${ }^{8}$ Fumitaka Oyama, ${ }^{8}$ \\ Peter De Jonghe, ${ }^{4,5,6,7}$ and Lori L. Isom ${ }^{1,2}$ \\ ${ }^{1}$ Department of Pharmacology and Program in Neuroscience and ${ }^{2}$ Department of Pharmacology and Program in Cellular and Molecular Biology, University \\ of Michigan School of Medicine, Ann Arbor, Michigan 48109-5632, ${ }^{3}$ Universidad de Los Andes Medical School, Bogotá, Colombia, ${ }^{4}$ Neurogenetics Group, \\ Department of Molecular Genetics, Vlaams Instituut voor Biotechnologie, ${ }^{5}$ Laboratory of Neurogenetics, Institute Born-Bunge, ${ }^{6}$ University of Antwerp, and \\ ${ }^{7}$ Division of Neurology, University Hospital of Antwerp, BE-2000 Antwerpen, Belgium, and ${ }^{8}$ Molecular Neuropathology Group, RIKEN Brain Science \\ Institute, Saitama 351-0198, Japan
}

Dravet syndrome (also called severe myoclonic epilepsy of infancy) is one of the most severe forms of childhood epilepsy. Most patients have heterozygous mutations in $S C N 1 A$, encoding voltage-gated sodium channel $\mathrm{Na}_{\mathrm{v}} 1.1 \alpha$ subunits. Sodium channels are modulated by $\beta 1$ subunits, encoded by $S C N 1 B$, a gene also linked to epilepsy. Here we report the first patient with Dravet syndrome associated with a recessive mutation in $S C N 1 B$ (p.R125C). Biochemical characterization of p.R125C in a heterologous system demonstrated little to no cell surface expression despite normal total cellular expression. This occurred regardless of coexpression of $\mathrm{Na}_{\mathrm{v}} 1.1 \alpha$ subunits. Because the patient was homozygous for the mutation, these data suggest a functional $S C N 1 B$ null phenotype. To understand the consequences of the lack of $\beta 1$ cell surface expression in vivo, hippocampal slice recordings were performed in $S c n 1 b^{-/-}$versus $S c n 1 b^{+/+}$mice. Scn $1 b^{-/-}$CA3 neurons fired evoked action potentials with a significantly higher peak voltage and significantly greater amplitude compared with wild type. However, in contrast to the $S c n 1 a^{+/-}$model of Dravet syndrome, we found no measurable differences in sodium current density in acutely dissociated CA3 hippocampal neurons. Whereas $S c n 1 b^{-/}$mice seize spontaneously, the seizure susceptibility of $S c n 1 b^{+/-}$mice was similar to wild type, suggesting that, like the parents of this patient, one functional $S C N 1 B$ allele is sufficient for normal control of electrical excitability. We conclude that $S C N 1 B$ p.R125C is an autosomal recessive cause of Dravet syndrome through functional gene inactivation.

\section{Introduction}

Patients with Dravet syndrome [Online Mendelian Inheritance in Men (OMIM) database identification number 607208; also called severe myoclonic epilepsy of infancy] typically exhibit prolonged febrile seizures in the first year of life. Subsequently, multiple types of febrile and afebrile seizures occur.

Received May 27, 2009; revised July 21, 2009; accepted July 27, 2009.

This project was funded by members of the Partnership for Pediatric Epilepsy Research, which includes the American Epilepsy Society, the Epilepsy Foundation, and Parents Against Childhood Epilepsy (L.L.I.). This research was also supported by National Institutes of Health Grant MH059980 and a grant from the Ralph C. Wilson Jr. Medical Research Foundation (L.L.I.). G.A.P. was supported by a predoctoral fellowship from the Epilepsy Foundation of Greater Chicago and by a Scholarship for Faculty Training from Los Andes University. We acknowledge the expert technical assistance of Mi Jung Lim, Mark Karadshi, and Ryan Deisler and are grateful for the scientific advice of Dr. Jack Parent and Dr. Miriam Meisler. G.A.P. performed and analyzed all electrophysiology experiments (except for those described for L.F.L.-S.), all biochemistry experiments, all cell biology experiments, and immunostaining of acutely dissociated hippocampal neurons, and analyzed the seizure susceptibility experiments. L.R.F.C. performed genetic analyses of the proband, family members, and controls. L.F.L.-S. performed and analyzed the hippocampal action potential experiments as well as the whole-cell voltage-clamp experiments on acutely dissociated hippocampal neurons. E.A.S. generated the $\beta 1$ and p.R125C CDNA constructs. R.S.R.D. performed the seizure susceptibility experiments. C.C. and C.B.B.G. generated and genotyped the $S c n 1 b$ null mice. H.A.O. performed immunofluorescent analysis of optic nerves, and F.O., H.M., and N.N. provided the anti- $\beta 1_{\text {intra }}$ antibody.

Correspondence should be addressed to Dr. Lori L. Isom, Department of Pharmacology, University of Michigan School of Medicine, 3422 Med Scil, 1301 Catherine,SPC5632,Ann Arbor, MI 48109-5632.E-mail: lisom@umich.edu. D01:10.1523/JNEUROSCI.2475-09.2009

Copyright $\odot 2009$ Society for Neuroscience $\quad 0270-6474 / 09 / 2910764-15 \$ 15.00 / 0$
Seizures are difficult to control, often requiring polytherapy. Cognitive development is normal until $\sim 2$ years of age, when it slows or stagnates. All patients exhibit some level of mental retardation. Patients often exhibit other neurological abnormalities, including ataxia and pyramidal signs. Risk of death is high in this group, including patients with sudden unexpected death in epilepsy (Dravet et al., 2005; Wolff et al., 2006).

Forty to $85 \%$ of Dravet syndrome patients have mutations in SCN1A (Oguni et al., 2005; Korff and Nordli, 2006; Catterall et al., 2008), the gene encoding voltage-gated sodium channel $\mathrm{Na}_{\mathrm{v}} 1.1$. In most patients, mutations are acquired de novo (Fujiwara, 2006; Kearney et al., 2006), although some mutations are inherited (Gennaro et al., 2003; Morimoto et al., 2006). Sodium channels are multimeric protein complexes essential for action potential generation in excitable cells, including neurons. Sodium channels are composed of a central, pore-forming $\alpha$ subunit and two $\beta$ subunits: a non-covalently-linked $\beta 1$ or $\beta 3$ subunit and a disulfide-linked $\beta 2$ or $\beta 4$ subunit (Catterall, 2000; Brackenbury et al., 2008a). In the CNS, the most abundant $\alpha$ subunits are $\mathrm{Na}_{\mathrm{v}} 1.1, \mathrm{Na}_{\mathrm{v}} 1.2$, and $\mathrm{Na}_{\mathrm{v}} 1.6$ (Catterall et al., 2005). Therefore, it is not surprising that mutations in genes encoding these subunits lead to epilepsy.

Sodium channel $\beta 1$ subunits modulate channel voltage dependence and gating as well as channel cell surface expression 
(Isom et al., 1992, 1995). $\beta 1$ also participates in cell-cell and cell-matrix adhesion (Brackenbury et al., 2008a; Brackenbury and Isom, 2008). $\beta 1$-mediated homophilic cell adhesion in vitro results in cellular aggregation, ankyrin recruitment, and neurite outgrowth (Malhotra et al., 2000, 2004; Davis et al., 2004). In vivo, the loss of $\beta 1$ results in spontaneous seizures, ataxia, and aberrant neuronal pathfinding and fasciculation (Chen et al., 2004; Brackenbury et al., 2008b). SCN1B, encoding $\beta 1$ (Isom et al., 1992), gives rise to at least two splice variants, $\beta 1$ and $\beta 1_{\mathrm{B}}$, that differ in their C-terminal domains (Kazen-Gillespie et al., 2000; Qin et al., 2003).

Heterozygous mutations in $S C N 1 B$ have been reported in patients with generalized epilepsy with febrile seizures plus type 1 $($ GEFS + 1) (OMIM identification number 604233) (Wallace et al., 1998, 2002; Audenaert et al., 2003; Burgess, 2005; Yamakawa, 2005; Scheffer et al., 2007). GEFS + is an epilepsy syndrome that includes mild to severe forms of epilepsy, with Dravet syndrome classified on the most severe side of the spectrum. All GEFS+ patients with $S C N 1 B$ mutations reported to date fall in the mild-to-moderate range of seizure severity, comprising febrile seizures, febrile seizures plus, early-onset absence epilepsy, mildto-moderate generalized epilepsies, and focal epilepsies. Here we report the first case of Dravet syndrome caused by an SCN1B homozygous mutation and explore the mechanisms by which this mutation may cause disruptions in the control of electrical excitability.

\section{Materials and Methods}

Genetic analysis. Mutation analysis of the six exons and intron-exon boundaries of $S C N 1 B$ was performed on genomic DNA of the patient by PCR sequencing. Primer sequences can be obtained on request. Purified PCR products were subsequently sequenced using the ABI BigDye Terminator cycle sequencing kit version 3.1 and analyzed on an ABI 3730 automated Sequencer (Applied Biosystems). Automated variation [single nucleotide polymorphisms (SNPs) and indels] discovery was performed using novoSNP (Weckx et al., 2005). Pyrosequencing with the PSQ96 System (Pyrosequencing AB) was used to confirm the presence of the mutation in the patient and to exclude it from the parents and a panel of 92 control individuals, of which 40 were of Moroccan origin, similar to the patient's family. DNA was extracted from peripheral blood of all participants. The Commission for Medical Ethics of the University of Antwerp approved this study, and participants or their legal representative signed an informed consent.

Mutations were numbered according to the published cDNA sequence (GenBank accession number NM_001037) with nucleotide +1 corresponding to the A of the ATG translation initiation codon, and the nomenclature followed the Mutation Database Initiative/Human Genome Variation Society mutation nomenclature recommendations (den Dunnen and Antonarakis, 2001).

To test for homozygosity, we genotyped four short tandem repeat (STR) markers distributed over $5 \mathrm{Mb}$ surrounding SCN1B. The markers were amplified in one multiplex PCR reaction and analyzed on an ABI 3730 automated Sequencer (Applied Biosystems).

Animals. Female Xenopus laevis frogs were obtained from Xenopus I and housed in cages filled with distilled water and protected from light. Frog chow was available ad libitum. Recovery of oocytes was performed as described below and previously (Fein et al., 2007). Frogs were allowed to recover at least 2 weeks between surgeries, and consecutive surgeries took place on opposite sides of the abdomen for each individual frog.

Scn $1 b^{-/-}$and $S c n 1 b^{+/+}$mice, congenic on the C57BL/6 background for at least 15 generations, were generated from $\mathrm{Scn} 1 b^{+/-}$mice as described previously (Chen et al., 2004). Animals were housed in the Unit for Laboratory Animal Medicine at the University of Michigan. All procedures were performed in accordance with University of Michigan guidelines for animal use and care.
Antibodies. Primary antibodies used in these studies were as follows: anti- $\beta 1_{\text {intra }}$ (1:1000 dilution) (Oyama et al., 2006; Chen et al., 2007), anti-V5 monoclonal antibody (1:2000; AbD Serotec), or anti- $\alpha$-tubulin monoclonal antibody (1:10,000; Cedarlane Laboratories). The specificity of anti- $\beta 1_{\text {intra }}$ has been reported previously using Western blot analysis of $S c n 1 b^{+/+}$and $S c n 1 b^{-/-}$brain membranes (Chen et al., 2007). To test the specificity of anti- $\beta 1_{\text {intra }}$ using immunofluorescence, we labeled $S c n 1 b^{+/+}$and Scn $1 b^{-/-}$optic nerve nodes of Ranvier as described previously (Chen et al., 2004) (supplemental Fig. $1 A, B$, available at www. jneurosci.org as supplemental material). $\operatorname{Scn} 1 b^{+/+}$nerves showed $\beta 1$ immunofluorescence in the nodal gap with caspr marking the paranodal regions, as expected. In contrast, $S c n 1 b^{-1-}$ nerves showed paranodal caspr staining but no $\beta 1$ signal in the nodes. To test the specificity of the anti-V5 antibody, membrane preparations from rat or $\mathrm{Scn} 1 b^{-/-}$ mouse brains or V5-tagged p.R125C-transfected or untransfected 1610 cells (West et al., 1992; Chen et al., 2004) were analyzed by Western blot, as described below. No immunoreactive bands were detected in rat or mouse brain or untransfected cells. In contrast, V5-tagged p.R125C was detected in the transfected cells by the anti-V5 antibody (supplemental Fig. 1C, available at www.jneurosci.org as supplemental material). Secondary antibodies used in these studies were HRP-conjugated goat anti-rabbit or anti-mouse (Pierce) diluted 1:2000 and Alexa Fluor 568 anti-rabbit (Invitrogen). Cell nuclei were counterstained with 4',6-diamidino-2-phenylinodole (DAPI) ( $10 \mu \mathrm{g} / \mathrm{ml}$; Sigma).

Expression vectors. p.R125C cDNA was generated by PCR using human $\beta 1 \mathrm{cDNA}$ in pcDNA3 as the template while simultaneously introducing the mutation by site-directed mutagenesis. For the experiments in mammalian cells, p.R125C cDNA was inserted into pcDNA3.1 Hygro(+), as was the human $\beta 1 \mathrm{cDNA}$ ( $\beta 1 \mathrm{WT}$ ), and the sequences of both constructs were confirmed. From these plasmids, cDNAs were amplified by PCR to remove the stop codon and then inserted into pcDNA3.1/V5-HIS using the pcDNA3.1/V5-HIS TOPO TA Expression kit (Invitrogen), according to the instructions of the manufacturer, to produce the V5-HIStagged subunits. Again, the sequences of both plasmids were confirmed. PCR primers and conditions for all reactions are available on request.

For oocyte expression, p.R125C cDNA was inserted into pSP64t-BXN (Meadows et al., 2002). $\beta 1 \mathrm{WT}-\mathrm{pSP} 64 \mathrm{t}-\mathrm{BXN}$ was generated as described previously (Meadows et al., 2002). The plasmid encoding rat $\mathrm{Na}_{\mathrm{v}} 1.2$ has been described previously (Fein et al., 2007).

Cell lines. All cell lines were maintained at $37^{\circ} \mathrm{C}$ with $5 \% \mathrm{CO}_{2}$, with the exception of the $27^{\circ} \mathrm{C}$ growth experiment, as indicated. HEK-293 cells expressing human $\mathrm{Na}_{\mathrm{v}} 1.1\left(\mathrm{HEKhNa}_{\mathrm{v}} 1.1\right)$ were obtained from GlaxoSmithKline under a materials transfer agreement and maintained in DMEM supplemented with $10 \%$ heat inactivated fetal bovine serum (HI-FBS), $200 \mu \mathrm{g} / \mathrm{ml} \mathrm{G418,} \mathrm{0.1 \%} \mathrm{non-essential} \mathrm{amino} \mathrm{acids,} 100 \mathrm{U}$ plus $100 \mu \mathrm{g} / \mathrm{ml}$ penicillin/streptomycin, and $0.25 \mu \mathrm{g} / \mathrm{ml}$ Fungizone (all from Invitrogen). HEKrNa 1.1 cells are HEK-293 derived and stably express the rat $\mathrm{Na}_{\mathrm{v}} 1.1$ subunit. These cells were cultured in MEM with Earle's salts, supplemented with $10 \%$ HI-FBS, $1 \%$ Glutamax, $1 \%$ sodium pyruvate, $1 \%$ non-essential amino acids mix, $100 \mathrm{U}$ plus $100 \mu \mathrm{g} / \mathrm{ml}$ penicillin/ streptomycin, $400 \mu \mathrm{g} / \mathrm{ml}$ Zeocin, and $0.25 \mu \mathrm{g} / \mathrm{ml}$ Fungizone (all from Invitrogen). Untransfected HEK-293 cells were maintained in this medium in the absence of Zeocin. SNaIIa cells are derived from Chinese hamster lung 1610 cells and stably express the rat $\mathrm{Na}_{\mathrm{v}} 1.2$ subunit (West et al., 1992). They were cultured in DMEM with low glucose, L-glutamine, and sodium pyruvate, supplemented with 5\% HI-FBS, $100 \mathrm{U}$ plus 100 $\mu \mathrm{g} / \mathrm{ml}$ penicillin/streptomycin, $400 \mu \mathrm{g} / \mathrm{ml} \mathrm{G418}$, and $0.25 \mu \mathrm{g} / \mathrm{ml}$ Fungizone. The 1610 cells were maintained in this medium in the absence of G418. All cells were transfected with Fugene 6 transfection reagent (Roche) according to the instructions of the manufacturer.

For electrophysiology experiments using transient transfection, $2 \mu \mathrm{g}$ of the cDNAs encoding wild-type or mutant $\beta 1$ subunits were cotransfected with $0.5 \mu \mathrm{g}$ of enhanced green fluorescent protein (EGFP), using pEGFP-N3 (Clontech) as a marker. Twenty-four hours later, the cells were passaged into $35 \mathrm{~mm}$ Petri dishes (Falcon). Twenty-four to $48 \mathrm{~h}$ later, whole-cell patch-clamp recordings were performed at room temperature, using an Axopatch 200B amplifier (Molecular Devices). The presence or absence of EGFP did not affect the results obtained (data not shown). Cells were visualized using an epifluorescence-equipped in- 
verted microscope (Carl Zeiss Axovert 25). For biochemical experiments using transient transfections, $3 \mu \mathrm{g}$ of the cDNAs encoding wild-type or mutant $\beta 1$ subunits were transfected into $\mathrm{HEKhNa}_{\mathrm{v}} 1.1$ cells. Twentyfour to $48 \mathrm{~h}$ after transfection, the cells were trypsinized and processed for whole-cell lysates or cell surface biotinylation experiments as described below.

To generate stable cell lines, $2.5 \mu \mathrm{g}$ of $\beta 1 \mathrm{cDNAs}$ were transfected, and, $24 \mathrm{~h}$ later, cells were passed into new medium containing selective antibiotics $[400 \mu \mathrm{g} / \mathrm{ml}$ Hygromycin (Invitrogen) for untagged $\beta 1$ subunit

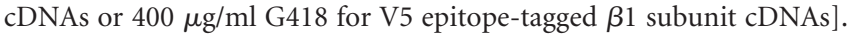
The cells were then incubated for several days until cell colonies were visible, when they were isolated and grown until reaching 95\% confluence as in the study by Isom et al. (1995). Cell clones were then passaged for biochemical and electrophysiological characterization.

Whole-cell patch-clamp analysis. Micropipettes were obtained from capillary glass tubing (Warner Instruments) using a horizontal P-97 puller (Sutter Instruments). Electrode resistance was between 1.5 and 3.5 $\mathrm{M} \Omega$. Voltage pulses were applied and data recorded using Clampex 9.2 and a Digidata 1322A digitizer (Molecular Devices). Pipette and wholecell capacitance were fully compensated, and the series resistance compensation was set to $\sim 80 \%$ with the lag set no more than $15 \mu \mathrm{s}$. Residual linear currents were subtracted using the $\mathrm{p} / 4$ procedure online, except for current rundown recordings. Signals were low-pass filtered at $5 \mathrm{kHz}$, and data were sampled at $40 \mathrm{kHz}$ online. Extracellular solution contained (in mм): $130 \mathrm{NaCl}, 4 \mathrm{KCl}, 1.5 \mathrm{CaCl}_{2}, 1 \mathrm{MgCl}_{2}, 5$ glucose, 10 HEPES. Intracellular solution contained the following (in mM): $20 \mathrm{CsF}, 95 \mathrm{CsCl}, 10$ $\mathrm{NaCl}, 10$ EGTA, and 10 HEPES. To determine the sodium current amplitude and voltage dependence of activation, currents were evoked by depolarization to different $250 \mathrm{~ms}$ test pulses (from -120 to $-70 \mathrm{mV}$ at $10 \mathrm{mV}$ intervals, from -70 to $-10 \mathrm{mV}$ at $5 \mathrm{mV}$ intervals, and from -10 to $50 \mathrm{mV}$ at $10 \mathrm{mV}$ intervals) from a holding potential of $-90 \mathrm{mV}$ and a hyperpolarizing $-120 \mathrm{mV}, 500 \mathrm{~ms}$ prepulse. Peak currents were normalized to cell capacitance and used to plot $I-V$ curves and to calculate conductance ( $g=I /\left(V-V_{\text {rev }}\right)$, where $V$ is the test potential, and $V_{\text {rev }}$ is the measured reversal potential). Voltage dependence of inactivation was determined by applying a $50 \mathrm{~ms}$ test pulse of $0 \mathrm{mV}$ after $250 \mathrm{~ms}$ prepulses to the same voltages as described for the voltage dependence of activation. Peak currents were normalized to the peak current amplitude. Normalized voltage conductance and inactivation curves were fit with the Boltzmann equation $1 /\left[1+\exp \left(V-V_{1 / 2}\right) / k\right]$, where $V_{1 / 2}$ is the membrane potential in the midpoint of the curve, and $k$ is a slope factor. To assess the time course of recovery from inactivation, a pulse to $0 \mathrm{mV}$ for $20 \mathrm{~ms}$ was followed by a recovery interpulse of variable duration (from 0.2 to $750 \mathrm{~ms}$ ) to $-110 \mathrm{mV}$ and then a $20 \mathrm{~ms}$ test pulse to $0 \mathrm{mV}$ to determine the fraction of recovered channels. Peak currents during the test pulse were normalized to the peak current during the corresponding prepulse and plotted as fractional recovery $\left(\mathrm{F}_{\mathrm{r}}\right)$ against time. Data were then fit with a double exponential to determine the time constants for recovery, using the equation $\mathrm{F}_{\mathrm{r}}=\left(\mathrm{F}_{\mathrm{f}}{ }^{*}\left(1-\exp \left((-x) / \tau_{\mathrm{f}}\right)\right)\right)+\left(\mathrm{F}_{\mathrm{s}}{ }^{*}(1-\right.$ $\left.\left.\exp \left((-x) / \tau_{\mathrm{s}}\right)\right)\right)$, where $\mathrm{F}_{\mathrm{f}}$ and $\mathrm{F}_{\mathrm{s}}$ are the proportions of fast and slow recovery, respectively. $\tau_{\mathrm{f}}$ and $\tau_{\mathrm{s}}$ are the fast and slow constants of recovery, respectively. For those cells that fit better with only one exponential, $\mathrm{F}_{\mathrm{s}}$ was considered to be 0 for statistical analysis. The kinetics of inactivation were measured on the test pulse to $0 \mathrm{mV}$ from the same protocol used for voltage dependence of activation. The current from $90 \%$ of the peak amplitude to $20 \mathrm{~ms}$ after the test pulse was fitted by the Chebyshev method to the equation $I=\left(\mathrm{F}_{\mathrm{f}}^{*} e^{-t / \tau_{\mathrm{f}}}\right)+\left(\mathrm{F}_{\mathrm{s}}{ }^{*} e^{-t / \tau_{\mathrm{s}}}\right)+C$, where $I$ is the current, and $C$ is the steady-state persistent current. The presence of persistent current was measured with the same protocol as above, from 245 to $250 \mathrm{~ms}$ after the test pulse was started, averaging the current in the segment and then normalizing against the peak current during the test pulse. To measure use-dependent rundown, a $10 \mathrm{mV}$ pulse was given from a $-100 \mathrm{mV}$ holding potential, at a frequency of $80 \mathrm{~Hz}$. Residual linear currents were subtracted using the $\mathrm{p} / 4$ procedure offline. Peak current was measured and normalized to the peak current of the first pulse and then plotted against pulse number (Meadows et al., 2002; Lopez-Santiago et al., 2007). Analysis of the recorded currents was performed using the software packages Clampfit 9.0.2 (Molecular Devices) and Origin 7 (OriginLab).
Two-electrode voltage-clamp recordings. Plasmids containing the cDNAs encoding rat $\mathrm{Na}_{\mathrm{v}} 1.2$, rat $\beta 1 \mathrm{WT}$, or human p.R125C were linearized using XhoI ( $\left.\mathrm{Na}_{\mathrm{v}} 1.2\right)$, EcoRI ( $\left.\beta 1 \mathrm{WT}\right)$, or ApaI plus NotI (p.R125C). mRNA was synthesized from the linearized plasmids using T7 $\left(\mathrm{Na}_{\mathrm{v}} 1.2\right)$ or SP6 ( $\beta 1$ WT and p.R125C) mMessage mMachine RNA Synthesis kits (Ambion). The resultant cRNAs were resuspended in RNA resuspension buffer ( 5 mм HEPES and $0.1 \mathrm{~mm}$ EDTA, pH 7.5), and $1 \mu \mathrm{l}$ of each preparation was analyzed by agarose-formaldehyde gel electrophoresis. Total cRNA yields for each preparation were estimated by comparison of the intensities of ethidium bromide-stained bands on the gels. After being anesthetized with 3 -aminobenzoic acid ethyl ester (tricaine, $0.2 \%$; Sigma) and under aseptic conditions, lobes of ovary were removed through a paramedian incision from female Xenopus laevis. Muscle and peritoneum were closed together with catgut, followed by skin using the same type of suture. The lobes containing oocytes were manually teased and then washed twice in OR2 (in mM: $82.5 \mathrm{NaCl}, 2 \mathrm{KCl}, 1 \mathrm{MgCl}_{2}$, and 5 HEPES, pH 7.5), defolliculated, and separated by shaking in collagenase type I ( $1.5 \mathrm{mg} / \mathrm{ml}$; Sigma). Healthy stage V-VI oocytes were selected and incubated overnight at $18^{\circ} \mathrm{C}$ in Barth's medium (in mM: $88 \mathrm{NaCl}, 1 \mathrm{KCl}$, $0.82 \mathrm{MgSO}_{4}, 0.33 \mathrm{Ca}\left(\mathrm{NO}_{3}\right)_{2}, 0.41 \mathrm{CaCl}_{2}, 2.4 \mathrm{NaHCO}_{3}$, and $10 \mathrm{HEPES}$, pH 7.4), supplemented with $50 \mu \mathrm{g} / \mathrm{ml}$ gentamycin (Fein et al., 2007). On the second day, oocytes were microinjected with $50 \mathrm{nl}$ of cRNA in the following combinations: $\alpha$ subunit alone, $\alpha$ plus $\beta 1 \mathrm{WT}$, or $\alpha$ plus p.R125C. We used an approximately fivefold concentration of $\alpha: \beta 1$ and equivalent concentrations of $\beta 1 \mathrm{WT}$ and p.R125C. After $16-48 \mathrm{~h}$ of incubation at $18^{\circ} \mathrm{C}$, two-electrode voltage-clamp recordings were performed at room temperature, using a Turbo TEC-10C amplifier (NPI Electronic). Micropipettes were obtained from capillary glass with internal filament (A-M Systems) using a horizontal puller P-97. Electrode resistance was between 0.5 and $1.5 \mathrm{M} \Omega$. Voltage pulses were applied, and data were recorded using Clampex and a Digidata 1322A digitizer. Residual linear currents were subtracted using the $\mathrm{p} / 4$ procedure. Signals were low-pass filtered at $2 \mathrm{kHz}$, and data were sampled at $20 \mathrm{kHz}$ online. Oocytes were continuously perfused with Ringer's solution (in mM: 115 $\mathrm{NaCl}, 2.5 \mathrm{KCl}, 1.8 \mathrm{CaCl}_{2}$, and 10 HEPES, $\mathrm{pH}$ 7.2) to which choline solution was sometimes substituted for sodium to obtain adequate voltage control (Patton and Goldin, 1991; Meadows et al., 2002; Fein et al., 2007). To examine the electrophysiological properties of sodium currents in oocytes, similar protocols and analyses were used as described for the mammalian cell lines with the following modifications. To determine the voltage dependence of activation, the peak currents were evoked by depolarization with $90 \mathrm{~ms}$ pulses, from -100 to $55 \mathrm{mV}$ in $5 \mathrm{mV}$ increments, from a holding potential of $-80 \mathrm{mV}$. Voltage dependence of inactivation was determined by applying $90 \mathrm{~ms}$ prepulses to potentials ranging from -100 to $55 \mathrm{mV}$, followed by a test pulse of $0 \mathrm{mV}$ for $80 \mathrm{~ms}$. To assess the time course of recovery from inactivation, a pulse of $0 \mathrm{mV}$ for $5 \mathrm{~ms}$ was followed by a recovery prepulse of variable duration to -80 $\mathrm{mV}$ and a test pulse to $0 \mathrm{mV}$.

Western blot analysis of cell lysates. For each experiment, stably transfected cells from a $100 \mathrm{~mm}$ Petri dish or transiently transfected cells from a $60 \mathrm{~mm}$ dish at $95 \%$ confluence were pelleted, resuspended, and homogenized in Tris-EGTA buffer (50 mm Tris and $10 \mathrm{~mm}$ EGTA, pH 8 ) with Complete Mini protease inhibitor tablets (Roche) and centrifuged once again. Cell pellets were then resuspended in solubilization assay buffer (50 mм Tris, $10 \mathrm{~mm}$ EDTA, $150 \mathrm{~mm} \mathrm{NaCl}, 1.25 \% \mathrm{NP}-40$, $0.5 \%$ sodium deoxycholate, and $0.1 \%$ SDS) and incubated on ice for $20 \mathrm{~min}$. Nonsolubilized proteins were removed by centrifugation, and the resultant supernatant was mixed with loading buffer containing SDS and $\beta$-mercaptoethanol. Proteins were separated by SDS-PAGE on a $10 \%$ polyacrylamide gel and transferred to nitrocellulose membrane, and Western blot analysis was performed as described previously (McEwen et al., 2004). Incubations with both primary and secondary antibodies were performed at room temperature for $1 \mathrm{~h}$. Immunoreactive bands were detected using West Dura or West Femto chemiluminescent substrate (Thermo Fisher Scientific). Rat brain membranes were prepared as described previously (McEwen et al., 2004) and used as positive controls. Immunoreactive signals were quantified using NIH ImageJ software and normalized to the level of $\alpha$-tubulin. 
Surface biotinylation assays. Surface biotinylation assays were performed as described previously (Meadows et al., 2002) with slight modifications. Briefly, stably transfected cells were grown in tissue culture plates, and membrane proteins were biotinylated using the Cell Surface Labeling Accessory Pack (Thermo Fisher Scientific) following the instructions of the manufacturer. All samples were loaded on a $10 \%$ SDSPAGE gel and processed as described above.

Seizure induction in $\mathrm{S} \mathrm{cn} 1 \mathrm{~b}^{+/-}$and $\mathrm{Scn} 1 \mathrm{~b}^{+/+}$mice. Pentylenetetrazole (PTZ) (Sigma) was diluted in sodium chloride physiological solution (Fluka, Sigma) at room temperature. Postnatal day 18 (P18) to P21 $\mathrm{Scn}_{\mathrm{H}} b^{+/-}$and $\mathrm{S} c n 1 b^{+/+}$littermate mice were injected intraperitoneally at doses between 0 and $80 \mathrm{mg} / \mathrm{kg}$. Mice were observed for seizures in a large-sized cage that allowed exploration, with soft bedding, for $45 \mathrm{~min}$, during which seizures were classified according to the modified Racine scale (Racine, 1972; Cole et al., 2000; Witkin et al., 2007; Yilmaz et al., 2007). After the experiment, all animals were killed with an overdose of intraperitoneally administered sodium pentobarbital (Ovation Pharmaceuticals), followed by removal of vital organs.

Hippocampal slice recordings. Acute brain slices were prepared from P17-P19 Scn1b $b^{+/+}$and Scn $1 b^{-/-}$littermate mice. Brains were dissected and immersed in ice-cold dissection solution (in mM: 10 D-glucose, 4 $\mathrm{KCl}, 26 \mathrm{NaHCO}_{3}, 234$ sucrose, $2.5 \mathrm{MgCl}_{2}$, and $1.3 \mathrm{CaCl}_{2}$ ) within $30 \mathrm{~s}$. Each brain was then submerged in a chamber filled with ice-cold dissection solution and connected to a vibrating tissue slicer (Oxford vibratome sectioning system) for preparation of coronal hippocampal slices (400 $\mu \mathrm{m}$ thick). Slices were transferred to an incubation chamber containing circulating artificial CSF (ACSF) (in mM: $119 \mathrm{NaCl}, 2.5 \mathrm{KCl}, 1$ $\mathrm{NaH}_{2} \mathrm{PO}_{4}, 11$ glucose, $26 \mathrm{NaHCO}_{3}, 2.5 \mathrm{MgCl}_{2}$, and $1.3 \mathrm{CaCl}_{2}$ ) saturated with $5 \% \mathrm{CO}_{2}$ and $95 \% \mathrm{O}_{2}$ mix and held at $35^{\circ} \mathrm{C}$ for $1 \mathrm{~h}$. The slices were allowed to return to room temperature $\left(22-24^{\circ} \mathrm{C}\right)$ after the incubation period. Slices were then transferred to a recording chamber and continuously superfused with $30^{\circ} \mathrm{C}$ ACSF. All recordings were made $1-5 \mathrm{~h}$ after slicing. Patch pipettes were pulled from borosilicate glass using a Flaming/Brown micropipette puller. Whole-cell recordings from randomly chosen neurons were performed with a Multiclamp 700B amplifier (Molecular Devices). Patch pipettes (4-8 M $\Omega$ ) were filled with an internal solution [in mM: $115 \mathrm{~K}$-gluconate, $20 \mathrm{KCl}, 10 \mathrm{HEPES}, 2 \mathrm{MgCl}_{2}, 4 \mathrm{Na}_{2}$ ATP, and $3 \mathrm{Na}_{3}-\mathrm{GTP}$, pH 7.26 (290 mOsm)]. For current clamp, changes in membrane potential were recorded in CA1 and CA3 neurons after injecting currents ranging from -100 to $280 \mathrm{pA}$ in $20 \mathrm{pA}$ intervals. Resting membrane potentials and action potential (AP) properties were then analyzed using ClampFit 8.2. The initial AP generated in each experiment was analyzed as follows: cell resting membrane potential was recorded as the average resting membrane potential of all traces. Internal resistance was calculated using $V=I R$, where $V$ was the change in voltage from resting membrane potential to maximal negative voltage produced by the first injected current of $-100 \mathrm{pA}$ and $R$ is resistance. AP threshold was calculated at the onset of the AP. AP rise time was calculated as the change in time from the onset of the AP to the maximal voltage reached. AP amplitude was calculated as the change in voltage from the threshold voltage to the maximal voltage reached. Half-decay time was measured as the time required for the AP to decay to half of its maximal voltage. Finally, the maximum rates of depolarization and repolarization were measured from the AP differentiated waveform.

Sodium current recordings and $\beta 1$ immunocytochemistry in acutely dissociated CA3 hippocampal neurons. Acutely dissociated CA3 neurons were prepared from P10-P14 Scn $1 b^{-/-}$and $S c n 1 b^{+/+}$littermate mice. Brains were rapidly dissected and immersed in ice-cold high sucrose solution (in mM: 250 sucrose, 11 D-glucose, $0.5 \mathrm{KCl}, 1 \mathrm{NaH}_{2} \mathrm{PO}_{4}, 2$ $\mathrm{MgSO}_{4}$, and $2 \mathrm{CaCl}_{2}$ ) saturated with $\mathrm{O}_{2}$, for $2 \mathrm{~min}$. The brain was submerged in a chamber filled with ice-cold high-sucrose solution and connected to a vibratome tissue slicer (World Precision Instruments) to generate coronal hippocampal slices (300-350 $\mu \mathrm{m}$ thick). Slices were then transferred to a dish containing cold Na-isethionate solution (in mM: $140 \mathrm{Na}$-isethionate, 23 glucose, 15 HEPES, $2 \mathrm{KCl}, 4 \mathrm{MgCl}_{2}$, and 0.1 $\mathrm{CaCl}_{2}$ ), and the CA3 region was isolated. CA3 areas were transferred to a chamber containing bicarbonate-buffered holding solution (in mM: 126 $\mathrm{NaCl}, 2.5 \mathrm{KCl}, 1.25 \mathrm{NaH}_{2} \mathrm{PO}_{4}, 10$ glucose, $26 \mathrm{NaHCO}_{3}, 2 \mathrm{MgCl}_{2}, 2 \mathrm{CaCl}_{2}$, 1 pyruvic acid, 0.2 ascorbic acid, $0.1 \mathrm{~N}$-nitro-L-arginine, and 1 kynurenic acid) saturated with $5 \% \mathrm{CO}_{2}$ and $95 \% \mathrm{O}_{2}$ mix and held at room temperature $\left(21-22^{\circ} \mathrm{C}\right)$ for $1-6 \mathrm{~h}$. To dissociate neurons, two to three CA3 slices were incubated in HBSS (Invitrogen) supplemented with $0.2 \mathrm{~mm}$ ascorbic acid, and $1.25 \mathrm{mg} / \mathrm{ml}$ protease type XIV (Sigma) saturated with $\mathrm{O}_{2}$ for $20 \mathrm{~min}$. The HBSS solution was removed, and the slices were rinsed three times using cold Na-isethionate solution. After the final rinse, $300 \mu \mathrm{l}$ of this solution was left to triturate the tissue using silicon-coated Pasteur pipettes with progressively smaller tip sizes.

After mechanical dissociation, 100-150 $\mu$ l of cellular suspension were transferred to a dry glass coverslip. For sodium current recordings, the coverslip was placed inside of the recording chamber. After 5-10 $\mathrm{min}$, the $\mathrm{Na}$-isethionate solution was replaced by extracellular solution (in mM: $20 \mathrm{NaCl}, 1 \mathrm{BaCl}_{2}, 2 \mathrm{MgCl}_{2}, 55 \mathrm{CsCl}, 1 \mathrm{CdCl}_{2}, 1 \mathrm{CaCl}_{2}, 10 \mathrm{HEPES}$, 20 tetraethylammonium-Cl, and 100 glucose, $\mathrm{pH} 7.35$ with $\mathrm{CsOH}$ ). Voltage-clamp recordings were performed in the standard whole-cell configuration, using similar conditions to those described by LopezSantiago et al. (2006) using an Axopatch 200B voltage-clamp amplifier (Molecular Devices). Isolated sodium currents were recorded from single neurons (bipolar or pyramidal, as assessed by morphology) at $21^{\circ} \mathrm{C}$. Fire-polished patch pipettes were generated from borosilicate glass capillaries (Warner Instruments) using a P-87 puller (Sutter Instruments) and were filled with internal solution (in mM: $1 \mathrm{NaCl}, 150 \mathrm{~N}$-methyl-Dglucamine, 10 EGTA, $1 \mathrm{CaCl}_{2}, 2 \mathrm{MgCl}_{2}, 2 \mathrm{Na}_{2} \mathrm{ATP}, 0.05 \mathrm{GTP}, 10 \mathrm{HEPES}$, and 5 glucose, $\mathrm{pH} 7.3$ with $\mathrm{CsOH}$ ). All recordings were performed within 10-60 min after plating of cells on the coverslip.

For immunocytochemistry, dissociated neurons were transferred to BD BioCoat coverslips that were pretreated with poly-D-lysine and lami$\operatorname{nin}$ (BD Biosciences). After allowing the neurons to rest on the coverslip for $20 \mathrm{~min}$, the neurons were fixed with $4 \%$ paraformaldehyde for an additional $20 \mathrm{~min}$. After three washes with PBS, the coverslips were incubated in block solution ( $5 \%$ nonfat dry milk, $1 \%$ bovine serum albumin fraction V, and $0.025 \%$ Triton X-100 from Sigma, in PBS) for $1 \mathrm{~h}$. Incubation overnight at $4^{\circ} \mathrm{C}$ with primary antibody (anti- $\beta 1_{\text {intra }}$ at a 1:500 dilution in block solution) was followed by three washes with block solution and $1 \mathrm{~h}$ incubation at room temperature with secondary antibody (Alexa Fluor anti-rabbit 568, 1:500 dilution). After three additional washes with block solution and PBS, each of the coverslips were incubated for $5 \mathrm{~min}$ at room temperature with DAPI. After a final wash with water for $20 \mathrm{~min}$, the coverslips were mounted on glass slides using $\mathrm{Gel} /$ Mount (Biomeda) and placed at $4^{\circ} \mathrm{C}$. Samples were viewed using a Fluoview 500 confocal laser-scanning microscope (Olympus) with $100 \times$ objective. Images $(1024 \times 1024$ pixels $)$ were acquired with the Olympus Optical Fluoview software and then exported into NIH ImageJ.

Statistical analyses. Data were tested for normality using the KolmogorovSmirnov test and for homogeneity of variances using the Levene test. Continuous variables with normal distribution were compared using two-tailed Student's $t$ test or ANOVA. If homogeneity of variance existed, Tukey's was selected as the post hoc test; otherwise, Tamhane's T2 was used. Discrete variables and continuous variables not normally distributed were compared using the Mann-Whitney $U$ test or KruskalWallis $H$ test. Statistical significance was set at a $p<0.05$. The version 13.0 for Windows of SPSS (SPSS Inc.) was used for all determinations of statistical significance.

\section{Results \\ Clinical evaluation}

This male patient was a dizygotic twin born after cesarean section at 39 weeks of gestation after a normal, uncomplicated pregnancy. His parents are first cousins of Moroccan origin. Both parents and his brother are healthy with no reported seizures. A history of epilepsy during adolescence was reported in a maternal aunt. At age 3 months, the patient developed generalized tonicclonic seizures after vaccination. During a subsequent hospitalization, he experienced a second generalized seizure. Treatment with valproic acid was started. The magnetic resonance image was normal, and EEG showed rolandic discharges. Five days after a new hospital admission, the patient developed fever-associated convulsions that occurred at a frequency of two to three per week. 
During the following month, he experienced several generalized myoclonias each day that were often associated with fever. Valproic acid doses were increased, and clobazam was added to the treatment without a clear reduction in seizure frequency. From the age of 5 months, the patient was repeatedly hospitalized for persistent myoclonias during episodes of infections. His mother reported a deterioration of psychomotor abilities. Myoclonias remained refractory to treatment with valproic acid, clonazepam, clobazam, and phenytoin. Clinical examination at the age of 13 months revealed a tetrapyramidal syndrome with pronounced global hypotonia. The patient died 3 weeks later as a result of respiratory insufficiency secondary to an aspiration pneumonia.

\section{Genetic analyses}

Mutation analysis for SCN1A was performed as described previously (Claes et al., 2001). No mutations in SCN1A were identified. The six coding exons of $S C N 1 B$ were analyzed next. All single nucleotide polymorphisms located in the amplicons of SCN1B were observed homozygously, and a novel homozygous mutation was identified in exon 3 (c.373C $>$ T), predicting a missense mutation of a highly conserved arginine residue $(\mathrm{R})$ at position 125 to cysteine (C) (Fig. 1A,B). p.R125 is located in the $\beta 1$ extracellular Ig domain, four amino acids downstream from the previously identified p.C121W GEFS + 1 mutation (Fig. 1C) (Wallace et al., 1998). Both parents were found to be heterozygous carriers of the mutation, which was not observed in the 92 control individuals tested. Genotyping of four STR markers in a $5 \mathrm{Mb}$ region surrounding $S C N 1 B$ revealed a common haplotype in both parents that was transmitted to the child (Fig. 1D). These data confirm that both mutated alleles from the child originated from the same ancestral haplotype, consistent with the consanguinity of the parents.

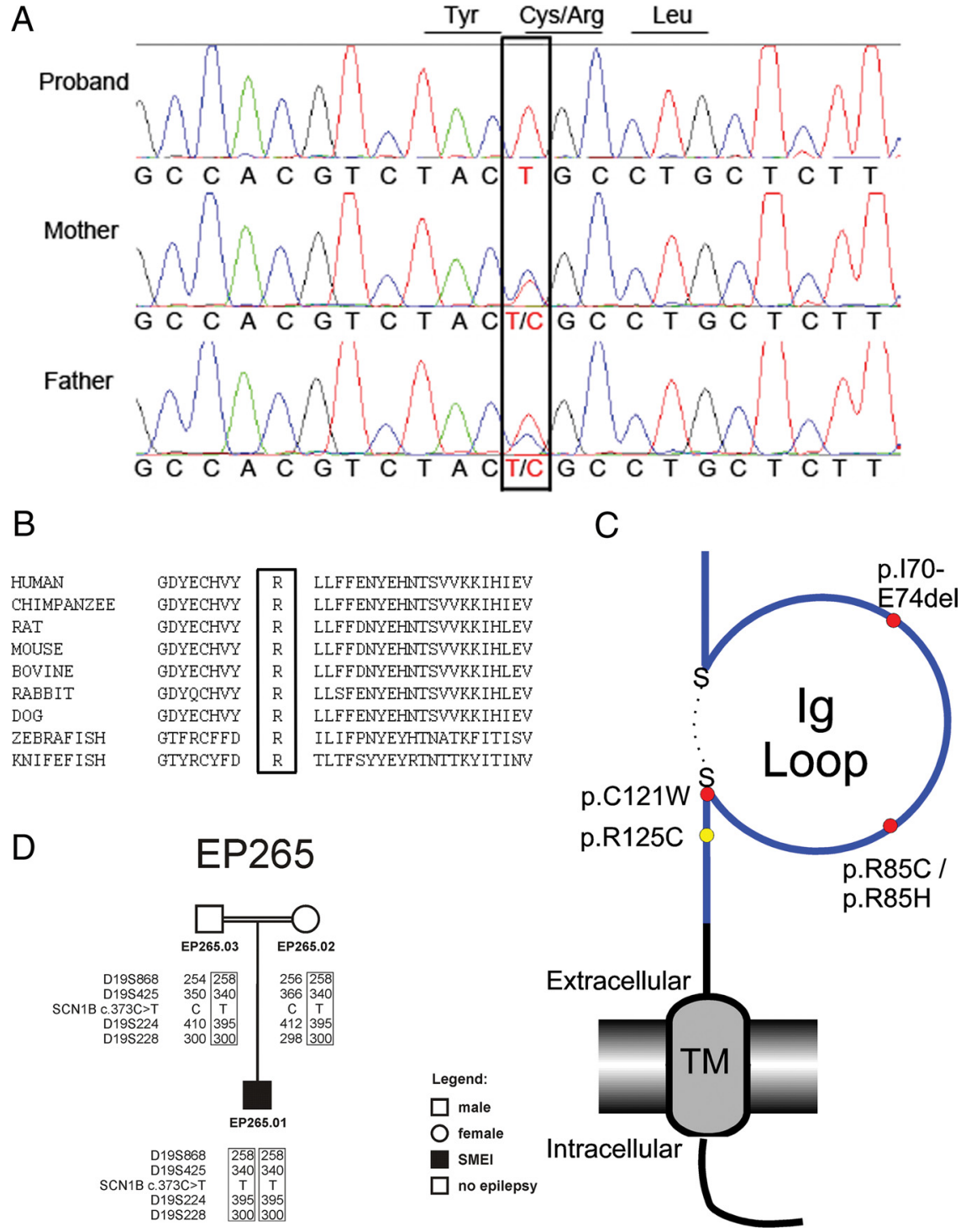

Figure 1. SCN1B homozygous mutation found in Dravet syndrome. $\boldsymbol{A}$, Chromatogram showing the C.373C $>$ T homozygous mutation in the SCN1B exon 3 amplicon in the proband (top lane), whereas both parents are heterozygous (bottom 2 lanes) for the mutation. The mutation results in a change of arginine $(R)$ at position 125 to cysteine $(C)$ in the amino acid sequence. $\boldsymbol{B}$, Alignment of the corresponding region of the sodium channel $\beta 1$ subunit amino acid sequence across multiple species showing the high conservation of p.R125. C, Topology of the sodium channel $\beta 1$ subunit. The extracellular domain contains an $\mathrm{lg}$ loop bound by a disulfide bridge $(S-S)$. A mutation in the distal cysteine of the disulfide bridge (p.C121; red circle) has been reported in families with GEFS +, as have two other mutations (p.170-E74del and p.R85C) p. $85 \mathrm{H}$; red circles). The amino acid position of the mutation found in the proband ( $\mathrm{R} . \mathrm{R} 125 \mathrm{C}$ ) is marked by the yellow circle. Domains shared by both splice variants, $\beta 1_{\text {and }} \beta 1_{\mathrm{B}}$, are shown in blue and include only the extracellular region. $\beta 1_{\mathrm{B}}$ contains a novel domain encoded by a retained intron. The transmembrane domain (TM) of $\beta 1$ is followed by a short intracellular domain. $\boldsymbol{D}$, The genotyping of four STR markers around the SCN1B site confirms the ancestral haplotype.

\section{Electrophysiological characterization of p.R125C in mammalian cell lines}

Previous mutations of SCN1B reported in epileptic patients have shown abnormalities in $\beta 1$-mediated channel gating properties when assayed in heterologous expression systems (Wallace et al., 1998; Meadows et al., 2002; Xu et al., 2007). In the following series of experiments, we assessed the effect of the p.R125C $\beta 1$ mutant subunit on currents expressed by $\mathrm{Na}_{\mathrm{v}} 1.1$ and $\mathrm{Na}_{\mathrm{v}} 1.2$ using the whole-cell patch-clamp technique in transfected mammalian cells.

To examine the effects of p.R125C on sodium currents expressed by $\mathrm{Na}_{\mathrm{v}} 1.1$, we transiently transfected HEK-293 cells that stably express rat $\mathrm{Na}_{\mathrm{v}} 1.1\left(\mathrm{HEKrNa}_{\mathrm{v}} 1.1\right)$ with wild-type human $\beta 1(\beta 1 \mathrm{WT})$ or $\mathrm{p} . \mathrm{R} 125 \mathrm{C} \mathrm{cDNA}$ as described in Materials and Methods. The rat $\mathrm{Na}_{\mathrm{v}} 1.1$ sequence (GenBank accession number NP_110502.1, Swissprot accession number P04774) exhibits a 98.16\% amino acid identity with human $\mathrm{Na}_{\mathrm{v}} 1.1$ (GenBank accession number NP_008851.3, Swissprot accession number P35498), predicting that effects of $\beta 1$ subunits should be similar on channel proteins from both species (Smith and Goldin, 1998; Vanoye et al., 2006). We found no significant difference in sodium current density (Fig. 2A), voltage dependence of activation or inactivation (Fig. $2 B, C$ ), kinetics of inactivation, or recovery from inactivation (Fig. $2 D$, Table 1 ) between cells expressing $\beta 1 \mathrm{WT}$ (GenBank accession number NP_001028.1, Swissprot accession 
A

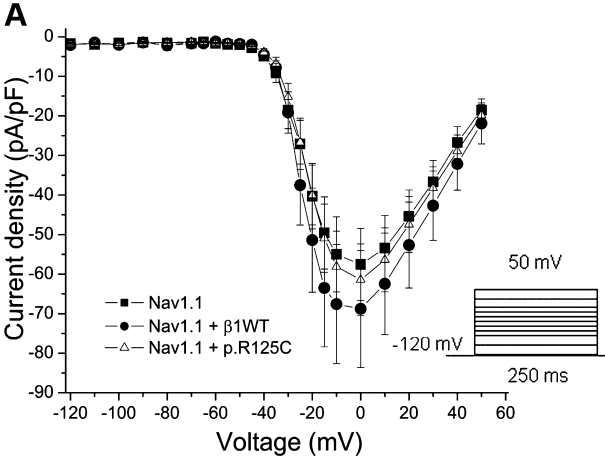

C

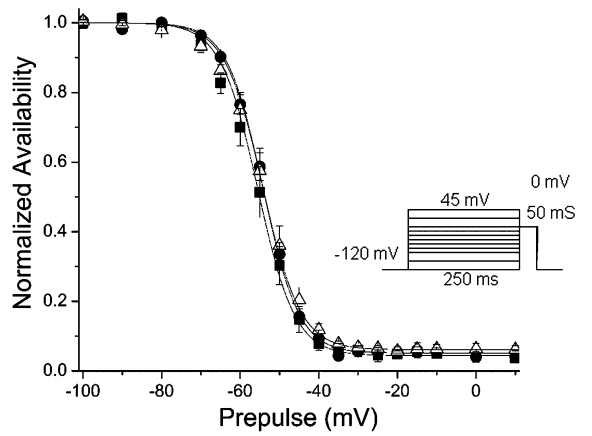

B

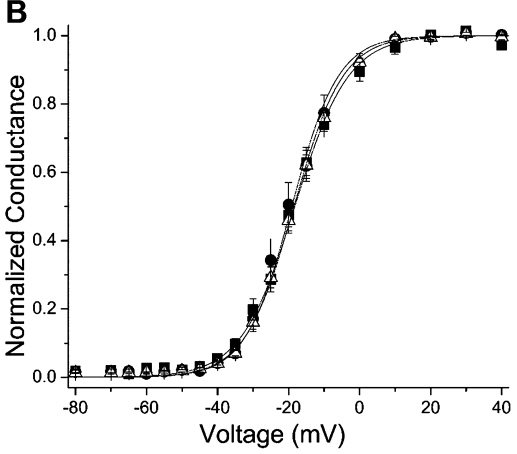

D

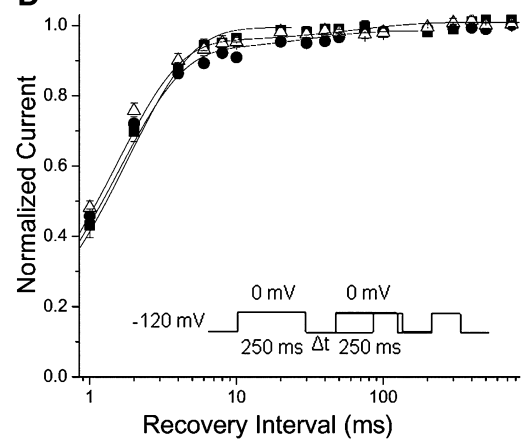

Figure 2. p.R125C and $\beta 1 \mathrm{WT}$ have no effect on the properties of sodium current in $\mathrm{HEKrNa}_{\mathrm{v}} 1.1$ cells. Cells stably expressing rat $\mathrm{Na}_{v} 1.1$ in a HEK-293 background ( $\left.\mathrm{HEKrNa}_{\mathrm{v}} 1.1\right)$ were transiently cotransfected with GFP and either $\beta 1 \mathrm{WT}$ (filled circles) or p.R125C (open triangles). HEKrNa 1.1 cells transfected only with EGFP (filled squares) were used as negative controls. Whole-cell patch-clamp recordings of sodium currents were performed as described in Materials and Methods. $\boldsymbol{A}, \boldsymbol{B}$, Sodium current density is unchanged in the presence and absence of $\beta 1$ subunits $(\boldsymbol{A})$, as is the voltage dependence of activation $(\boldsymbol{B}) . \boldsymbol{C}, \boldsymbol{D}$, A similar lack of effect from either transfected $\beta 1$ subunit is observed for the voltage dependence of inactivation $(\boldsymbol{C})$ and recovery from inactivation $(\boldsymbol{D})$. Insets depict the protocol scheme. $\boldsymbol{A}$ and $\boldsymbol{B}$ were obtained using the same protocol. Data points represent mean $\pm S E M$, and solid lines represent fit to the means. Biophysical properties are provided in Table 1.

Table 1. Biophysical parameters of sodium current in $\mathrm{HEKrNa}_{\mathrm{v}} 1.1$ cells compared with HEKrNa 1.1 cells coexpressing $\beta 1$ WT or $p . R 125 C$

\begin{tabular}{|c|c|c|c|}
\hline & HEKrNa 1.1 & HEKrNa $1.1+\beta 1 W T$ & HEKrNa $_{v} 1.1+p . R 125 C$ \\
\hline \multicolumn{4}{|l|}{$\begin{array}{l}\text { Voltage dependence } \\
\text { of activation }\end{array}$} \\
\hline$V_{1 / 2}(\mathrm{mV})$ & $-18.27 \pm 1.53$ & $-19.09 \pm 1.79$ & $-18.49 \pm 0.92$ \\
\hline$k$ & $-7.54 \pm 0.35$ & $-6.52 \pm 0.54$ & $-6.87 \pm 0.26$ \\
\hline$n$ & 12 & 9 & 11 \\
\hline \multicolumn{4}{|l|}{$\begin{array}{l}\text { Voltage dependence } \\
\text { of inactivation }\end{array}$} \\
\hline$V_{1 / 2}(\mathrm{mV})$ & $-55.52 \pm 1.32$ & $-54.18 \pm 0.77$ & $-54.30 \pm 1.47$ \\
\hline$k$ & $4.73 \pm 0.22$ & $4.59 \pm 0.13$ & $4.79 \pm 0.21$ \\
\hline$c$ & $0.04 \pm 0.01$ & $0.05 \pm 0.01$ & $0.60 \pm 0.01$ \\
\hline$n$ & 11 & 9 & 11 \\
\hline \multicolumn{4}{|l|}{$\begin{array}{l}\text { Kinetics of } \\
\text { inactivation, one } \\
\text { exponential }\end{array}$} \\
\hline$\tau_{\text {slow }}(\mathrm{ms})$ & $0.63 \pm 0.06$ & $0.42 \pm 0.03^{*}$ & $0.59 \pm 0.03$ \\
\hline$n$ & 11 & 8 & 10 \\
\hline \multicolumn{4}{|l|}{$\begin{array}{l}\text { Kinetics of } \\
\text { inactivation, two } \\
\text { exponentials }\end{array}$} \\
\hline$\tau_{\text {slow }}(\mathrm{ms})$ & $25.07 \pm 12.99$ & $6.95 \pm 3.18$ & $16.10 \pm 8.68$ \\
\hline Amplitude $_{\text {slow }}(\%)$ & $7.72 \pm 1.65$ & $4.43 \pm 2.35$ & $5.20 \pm 4.84$ \\
\hline$\tau_{\text {fast }}(\mathrm{ms})$ & $0.48 \pm 0.05$ & $0.34 \pm 0.01$ & $0.46 \pm 0.02$ \\
\hline Amplitude $_{\text {fast }}(\%)$ & $92.27 \pm 1.65$ & $95.56 \pm 2.35$ & $94.79 \pm 1.45$ \\
\hline$n$ & 11 & 8 & 10 \\
\hline
\end{tabular}

Data are mean \pm SEM. ${ }^{*} p<0.05$ compared with $\mathrm{Na}_{v} 1.1$. number Q07699) and those transfected with the p.R125C mutant. However, we also found no significant differences between cells expressing $\mathrm{Na}_{\mathrm{v}} 1.1$ alone compared with cells coexpressing $\beta 1 \mathrm{WT}$ subunits, in agreement with previous studies (Mantegazza and Cestèle, 2005; Rusconi et al., 2007; Cestèle et al., 2008). Similar results were obtained when we used HEK-293 cells stably expressing human $\mathrm{Na}_{\mathrm{v}} 1.1$ in place of the rat clone (data not shown). An effect of $\beta 1 W T$ on the kinetics of current inactivation of $\mathrm{Na}_{\mathrm{v}} 1.1$ has been reported previously (Aman et al., 2009). In agreement with that study, we found a statistically significant difference in the rate of inactivation comparing cells expressing $\mathrm{Na}_{\mathrm{v}} 1.1$ alone with those expressing $\beta 1 \mathrm{WT}$ using a single exponential for analysis. This difference, however, disappeared when the data were fit with two exponentials (Table 1). Using two exponentials, there was also no difference between the cells expressing $\beta 1 \mathrm{WT}$ compared with those expressing p.R125C.

As an alternative, we tested the p.R125C mutant in SNaIIa cells. We have published a number of papers using this cell line (Isom et al., 1995; Meadows et al., 2002; McEwen et al., 2004), Chinese hamster lung 1610 fibroblasts that stably express rat $\mathrm{Na}_{\mathrm{v}} 1.2$ (West et al., 1992) (GenBank accession number NP_036779.1, Swissprot accession number P04775). Previous studies have demonstrated multiple significant effects of $\beta 1$ coexpression with $\mathrm{Na}_{\mathrm{v}} 1.2$ in this heterologous system (Isom et al., 1995). Stable transfection of SNaIIa cells with $\beta 1 \mathrm{WT}$ or p.R125C cDNA was performed as described in Materials and Methods. Whole-cell patch-clamp analysis revealed expected changes in sodium current density (Fig. $3 A$ ), voltage dependence of activation and inactivation (Fig. $3 B, C$ ), kinetics of steady-state inactivation and recovery from inactivation (Fig. $3 D$, Table 2), persistent current (Table 2), and frequency dependence at $80 \mathrm{~Hz}$ for $\beta 1 \mathrm{WT}$ (Fig. $3 E$ ) (Isom et al., 1995; Meadows et al., 2002). In contrast, cells transfected with $p . R 125 C$ yielded results that were indistinguishable from untransfected SNaIIa cells (Fig. $3 A-E$ ), suggesting a lack of functional expression of this mutant $\beta 1$ subunit. We next attempted to express human $\mathrm{Na}_{\mathrm{v}} 1.1 \mathrm{cDNA}$ in 1610 cells to analyze the effect of $\beta 1$ and p.R125C on $\mathrm{Na}_{\mathrm{v}} 1.1$ channels in this background. Unfortunately, numerous experiments using three different transfection methods/reagents resulted in no measurable sodium currents.

\section{Cell surface expression of $\beta 1 W T$ versus p.R125C}

To investigate the mechanism underlying the inability of p.R125C $\beta 1$ to modulate sodium currents, we evaluated the level of total expression versus cell surface expression of p.R125C and $\beta 1 \mathrm{WT}$ subunit polypeptides. Experiments were performed in 1610 cells as well as in $\mathrm{HEKrNa}_{\mathrm{v}} 1.1$ cells that were stably transfected with $\beta 1 \mathrm{WT}$ or p.R125C. To be able to confirm our results using two different antibodies, we engineered a V5-His epitope tag on the C termini of $\beta 1 \mathrm{WT}$ and p.R125C, respectively, as 


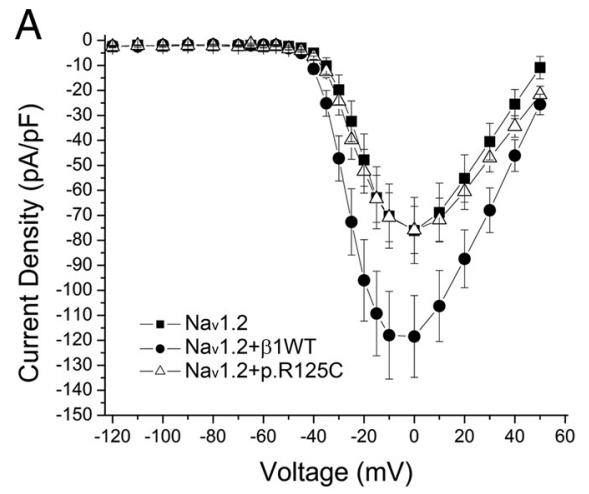

D

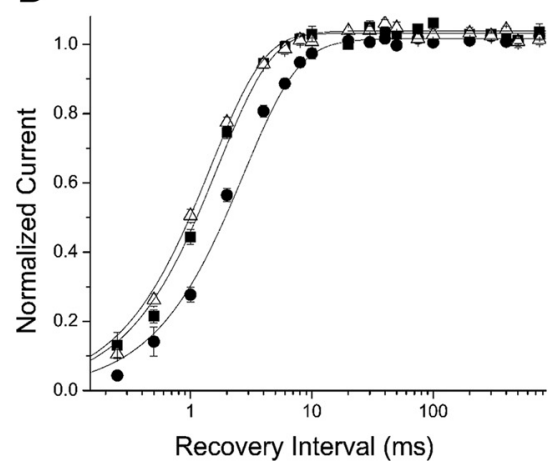

B

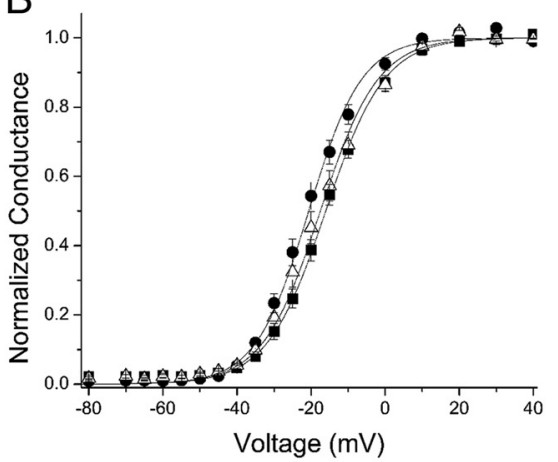

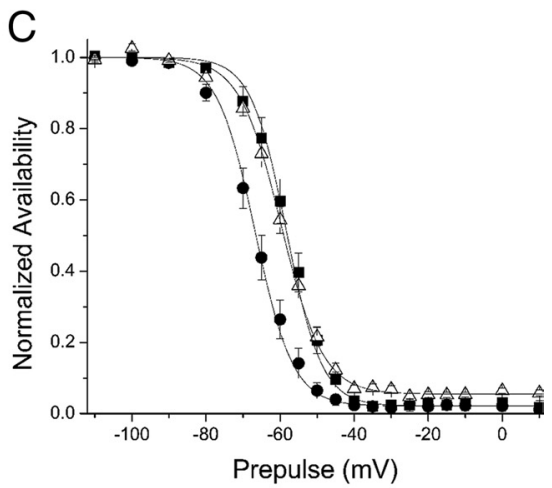

$\mathrm{E}$

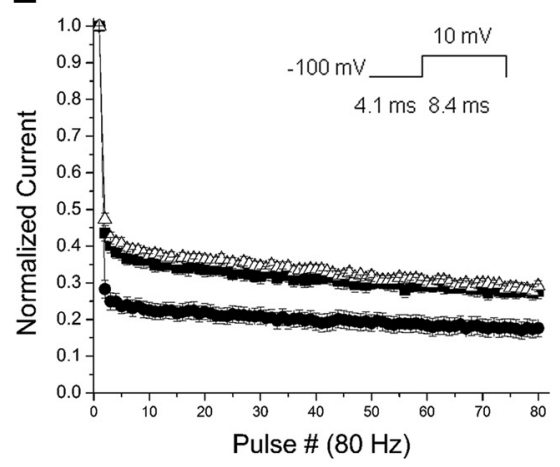

Figure 3. p.R125C does not modulate sodium current expressed by Na 1 1.2 in SNalla cells. SNalla cells were stably transfected with either $\beta 1 W T$ (filled circles) or p.R125C (open triangles) and used for whole-cell patch-clamp experiments as described in Materials and Methods. Untransfected cells (filled squares) were used as negative controls. $\beta 1$ WT increased the current density (A), negatively shifted the voltage dependence of activation $(\boldsymbol{B})$ and inactivation $(\boldsymbol{C})$, slowed the recovery from inactivation $(\boldsymbol{D})$, and reduced the availability of sodium channels under high-frequency stimulation (inset shows the protocol scheme) compared with cells expressing $\alpha$ alone (E). In contrast, p.R125C did not modulate sodium current properties. Protocols for $\boldsymbol{A}-\boldsymbol{D}$ are the same as in Figure 2. Biophysical properties can be found in Table 2.

Table 2. Biophysical parameters of sodium current in SNalla cells compared with SNalla cells coexpressing $\beta 1 W T$ or $p . R 125 C$

\begin{tabular}{|c|c|c|c|}
\hline & SNalla & SNalla $+\beta 1$ WT & SNalla + p.R125C \\
\hline \multicolumn{4}{|l|}{$\begin{array}{l}\text { Voltage dependence } \\
\text { of activation }\end{array}$} \\
\hline$V_{1 / 2}(\mathrm{mV})$ & $-16.04 \pm 1.02$ & $-20.63 \pm 1.22$ & $-17.50 \pm 1.50$ \\
\hline$k$ & $-7.92 \pm 0.46$ & $-7.15 \pm 0.22$ & $-7.79 \pm 0.38$ \\
\hline$n$ & 17 & 15 & 18 \\
\hline \multicolumn{4}{|l|}{$\begin{array}{l}\text { Voltage dependence of } \\
\text { inactivation }\end{array}$} \\
\hline$V_{1 / 2}(\mathrm{mV})$ & $-58.26 \pm 1.49$ & $-66.72 \pm 1.47^{*}$ & $-59.66 \pm 1.05^{\dagger}$ \\
\hline$k$ & $4.76 \pm 0.12$ & $5.11 \pm 0.08$ & $5.59 \pm 0.17$ \\
\hline$C$ & $0.02 \pm 0.01$ & $0.02 \pm 0.01$ & $0.05 \pm 0.00$ \\
\hline$n$ & 13 & 14 & 16 \\
\hline \multicolumn{4}{|l|}{ Kinetics of inactivation } \\
\hline$\tau_{\text {slow }}(\mathrm{ms})$ & $4.82 \pm 0.75$ & $6.26 \pm 1.20$ & $4.71 \pm 1.60$ \\
\hline Amplitude $_{\text {slow }}(\%)$ & $6.41 \pm 0.99$ & $0.04 \pm 0.00^{\ddagger}$ & $10.62 \pm 1.60^{\S}$ \\
\hline$\tau_{\text {fast }}(\mathrm{ms})$ & $0.57 \pm 0.02$ & $0.49 \pm 0.04$ & $0.56 \pm 0.33$ \\
\hline Amplitude $_{\text {fast }}(\%)$ & $93.58 \pm 0.99$ & $97.15 \pm 0.01^{\ddagger}$ & $89.37 \pm 1.60^{\S}$ \\
\hline$n$ & 12 & 14 & 10 \\
\hline \multicolumn{4}{|l|}{ Persistent current } \\
\hline$\%$ of peak current & $2.70 \pm 0.70$ & $0.00 \pm 0.00^{*}$ & $1.88 \pm 0.41^{\dagger}$ \\
\hline$n$ & 12 & 13 & 14 \\
\hline
\end{tabular}

Data are mean \pm SEM. ${ }^{*} p<0.005$ compared with $\mathrm{Na}_{\mathrm{v}} 1.2 .{ }^{\dagger} p<0.005$ compared with $\beta 1 \mathrm{WT} .{ }^{\ddagger} p<0.001$ compared with $\mathrm{Na}_{\mathrm{v}} 1.2 .{ }^{\S} p<0.001$ compared with $\beta 1 \mathrm{WT}$.

described in Materials and Methods, and used these constructs to generate additional stable cell lines in 1610 and $\mathrm{HEKrNa}_{\mathrm{v}} 1.1$ cells. Western blots were probed with anti-V5 antibody, as shown in Figure 4 , and these results were confirmed with anti- $\beta 1_{\text {intra }}$ antibody (data not shown). Similar results were obtained in cell lines expressing untagged $\beta 1$ subunits with Western blots probed with anti- $\beta 1_{\text {intra }}$ (data not shown). Comparison of total cellular protein levels of $\beta 1$ subunits in either 1610 cells (Fig. $4 A$ ) or $\mathrm{HEKrNa}_{\mathrm{v}} 1.1$ cells (data not shown) showed that the p.R125C mutant was expressed at a level comparable with that of the $\beta 1 \mathrm{WT}$ subunit. The average expression levels of multiple cell clones of both 1610 and $\mathrm{HEKrNa}_{\mathrm{v}} 1.1$ cells relative to $\alpha$-tubulin expression were compared by densitometry. There were no significant differences in the levels of total protein expression between wild-type $(0.91 \pm 0.11$ arbitrary units; $n=9)$ and mutant $\beta 1$ subunits ( $0.61 \pm 0.25$ arbitrary units; $n=12)$ in all of the cell lines tested ( $p=0.293$, Student's $t$ test). In contrast, in all cell lines tested, we observed that p.R125C was poorly expressed at the cell surface compared with $\beta 1 \mathrm{WT}$, in both the presence and absence of $\alpha$ subunits. Figure $4 B$ shows results of surface biotinylation for one $\mathrm{HEKrNa}_{\mathrm{v}} 1.1$ clone expressing $\beta 1 \mathrm{WT}$, two different $\mathrm{HEKrNa}_{\mathrm{v}} 1.1$ clones expressing p.R125C (samples 1 and 2), and three different 1610 clones expressing p.R125C (samples 3-5). The p.R125C-expressing cell lines showed barely detectable (sample 3) or no detectable (samples 1, 2, 4, and 5) levels of cell surface expression despite robust intracellular expression. For comparison, sample 4 in Figure $4 B$ is the same cell line used to demonstrate total cellular expression of the mutant subunit in Figure $4 A$ (lane p.R125C). Quantification of Western blot analyses of many biotinylated cell clones (in both 1610 cells and HEK$\mathrm{rNa}_{\mathrm{v}} 1.1$ cells) by densitometry using $\mathrm{NIH}$ Image showed that, on average, p.R125C cell surface expression was $6.7 \%$ of $\beta 1 \mathrm{WT}$ levels (Fig. $4 C$ ) ( $\beta 1 \mathrm{WT} n=18$ cell clones; p.R125C $n=15$ cell clones). To determine whether the cell surface expression of p.R125C was dependent on the presence of a 


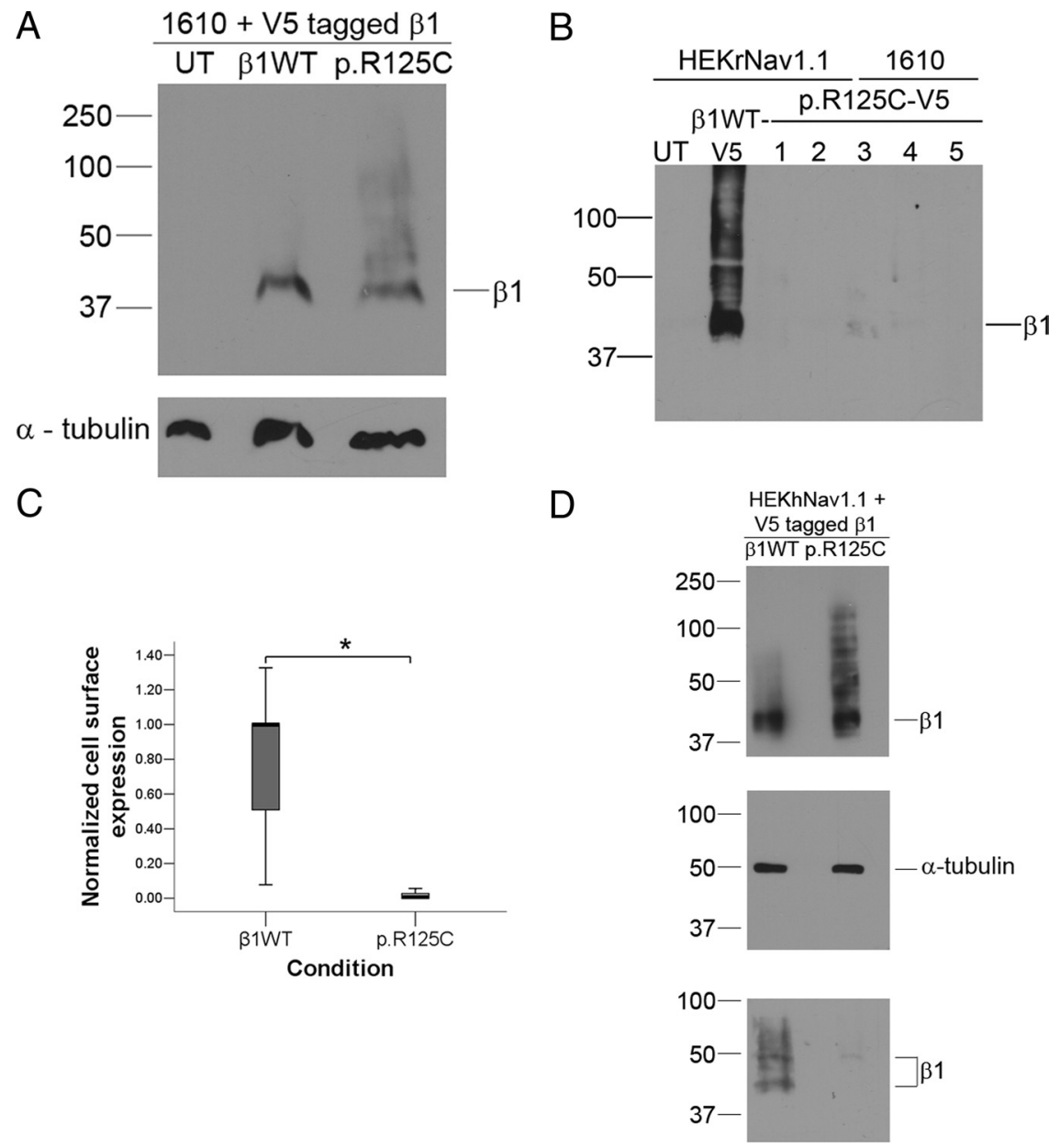

Figure 4. p.R125C is poorly expressed at the cell surface at physiological temperatures. $A$, Comparison of total cellular expression of $\beta 1$ WT versus p.R125C in 1610 cells. Representative Western blot of 1610 cells stably transfected with V5-tagged p.R125C (lane 3), demonstrating that the expression of the mutant protein is comparable with $\beta 1$ WT (lane 2). Untransfected cells (UT; lane 1) were used as a negative control. Reprobing the blot with anti- $\alpha$-tubulin confirmed the presence of protein in all lanes. $\boldsymbol{B}$, Cell surface expression of $\beta 1 W T$ versus p.R125C. HEKrNa 1.1 or 1610 cells stably transfected with V5-tagged $\beta 1$ WT or p.R125C were surface biotinylated, and the biotinylated proteins were probed as described in Materials and Methods. Untransfected cells show no anti-V5 immunoreactivity (UT; lane 1). Cells transfected with $\beta 1$ WT show robust cell surface expression (lane 2). Faint or no cell surface expression was detected in multiple clones of cells transfected with the mutant p. R125C ( $\mathrm{HEKrNa}_{v} 1.1$ cells, samples 1 and 2; 1610 cells, samples 3-5). For comparison, sample 4 is the same cell line used to detect total cellular expression in A, p.R125C.C, Box plots of band intensities measured using NIH Image f for clones of HEKrNa 1.1 and 1610 cells transfected with $\beta 1 \mathrm{WT}$ and p.R125C and processed to detect surface biotinylated proteins as described in Materials and Methods. We calculated a significant difference $\left({ }^{*} p<10^{-6}\right.$, Mann-Whitney $U$ test) between the level of cell surface expression of $\beta 1 \mathrm{WT}$ ( $n=18$ experiments) compared with p.R125C ( $n=15$ experiments). D, p.R125C is poorly expressed at the cell surface in the presence of human $\mathrm{Na}_{\mathrm{v}}$ 1.1. Top, Comparison of total cellular expression of $\beta 1 \mathrm{WT}$ versus $\mathrm{p} . \mathrm{R} 125 \mathrm{C}$ in HEKhNa $\mathrm{v}_{\mathrm{v}} 1.1$ cells. Representative Western blot of HEKhNa 1.1 cells stably transfected with V5-tagged p.R125C (lane 2), demonstrating that the expression of the mutant protein is comparable with $\beta 1 \mathrm{WT}$ (lane 1). Middle, Reprobing the blot with anti- $\alpha$-tubulin confirmed equal loading of protein in both lanes. Bottom, Cell surface expression of $\beta 1$ WT versus p.R125C. HEKhNa 1.1 cells transiently transfected with V5-tagged $\beta 1$ WT or p.R125C were surface biotinylated, and the biotinylated proteins were probed as described in Materials and Methods. Cells transfected with $\beta 1 W T$ show robust cell surface expression (lane 1). Faint or no cell surface expression was detected in cells transfected with the mutant p.R125C (lane 2). The blot is representative of triplicate experimental repeats. Molecular weight markers are in kilodaltons.

et al., 2007), can be rescued in vitro by incubation of cells at nonphysiological temperatures. To investigate whether a similar mechanism occurs with p.R125C, we grew a selected clone of V5-tagged p.R125C stably transfected 1610 cells in a humidified $\mathrm{CO}_{2}$ incubator at $27^{\circ} \mathrm{C}$ for $48 \mathrm{~h}$. This same p.R125C cell clone had no detectable cell surface expression at $37^{\circ} \mathrm{C}$ as assessed by surface biotinylation (Fig. 5 , $37^{\circ} \mathrm{C}$ lane). Surface biotinylation followed by Western blot analysis of this same cell line grown at $27^{\circ} \mathrm{C}$ demonstrated that p.R125C was expressed at the cell surface after the low-temperature incubation, suggesting that this mutant is trafficking deficient (Fig. $5,27^{\circ} \mathrm{C}$ lane).

\section{Sodium current modulation by p.R125C in Xenopus oocytes}

We observed that the p.R125C mutant $\beta 1$ subunit is expressed at significantly lower levels at the cell surface of mammalian cells grown at physiological temperatures compared with wild type and that this low level of surface expression is insufficient to modulate whole-cell sodium currents. To determine whether $\mathrm{p}$.R125C $\beta 1$ would be capable of current modulation if it did reach the cell surface, we coexpressed wild-type or mutant $\beta 1$ subunits with sodium channel $\alpha$ subunits in Xenopus oocytes. This model system has the advantages of expressing high levels of sodium channel $\alpha$ and $\beta$ subunit proteins (Fein et al., 2007) as well as growth under low-temperature conditions (Sigel and Minier, 2005) that, in our hands, promote p.R125C cell surface expression. We demonstrated previously that another GEFS + 1 mutant, p.C121W $\beta 1$, is robustly expressed in oocytes, in which it modulates sodium currents similar to wild-type $\beta 1$ despite a significant loss of functional modulation of current in mammalian cells grown at $37^{\circ} \mathrm{C}$ (Meadows et al., 2002). We measured sodium currents expressed by rat $\operatorname{Scn} 2 a$ (encoding $\mathrm{Na}_{\mathrm{v}} 1.2$ ) cRNA injected alone or currents expressed by the $\alpha$ subunit coinjected with rat $\beta 1 \mathrm{WT}$ (GenBank accession number NP_058984.1, Swissprot accession num-

human, rather than a rat, $\alpha$ subunit, we repeated the cell lysate and surface biotinylation experiments using the $\mathrm{HEKhNa}_{\mathrm{v}} 1.1$ cell line. As shown in Figure $4 D$, both $\beta 1 \mathrm{WT}$ and p.R125C were expressed at comparable levels in whole-cell lysates. In contrast and similar to results obtained in the HEKrNav1.1 line, only $\beta 1 \mathrm{WT}$ was detectable at the cell surface.

Many disease mutations have been shown to act through mechanisms involving trafficking deficiency to the cell surface (for review, see Gissen and Maher, 2007). Some of these mutants, including sodium channel $\alpha$ subunit mutations associated with GEFS+ and long QT syndrome (Valdivia et al., 2002; Rusconi ber Q00954; 96.33\% amino acid identity with human $\beta 1$ ) or p.R125C using the two-electrode voltage-clamp technique (Fig. 6 , Table 3 ). We observed that the effects of p.R125C $\beta 1$ on sodium current expressed by $\operatorname{Scn} 2 a$ (Fig. 6A-C, Table 3) were indistinguishable from $\beta 1 \mathrm{WT}$. To determine whether a lower level of p.R125C expression would result in the loss of current modulation by this mutant subunit in oocytes, we diluted the p.R125C mRNA stock 50 -fold before injection. In contrast to previous results with p.C121W $\beta 1$ (Meadows et al., 2002), we observed no reduction in $\mathrm{Na}_{\mathrm{v}} 1.2$ current modulation by p.R125C under these conditions (Fig. 6A-C, Table 3). Together, these data suggest 


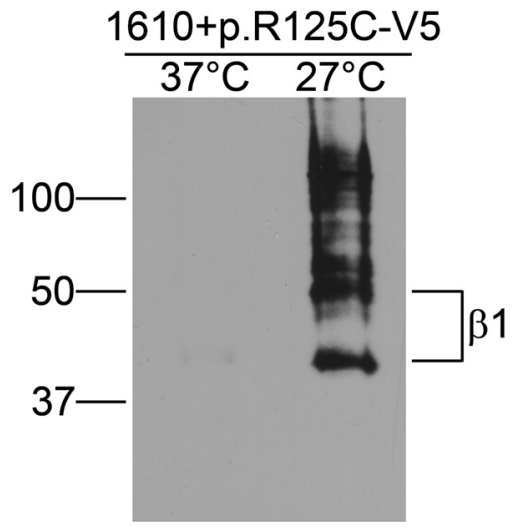

Figure 5. Cell surface expression of $p . R 125 \mathrm{C}$ is rescued at low temperature. The 1610 cells stably transfected with V5-tagged p.R125C were incubated at $37^{\circ} \mathrm{C}$ or $27^{\circ} \mathrm{C}$ for $48 \mathrm{~h}$ and then surface biotinylated as described in Materials and Methods. The resulting Western blot was probed with anti-V5 antibody. Incubation at $27^{\circ} \mathrm{C}$ rescued the cell surface expression of $p . R 125 C$, resulting in the presence of $\beta 1$-immunoreactive bands at $40 \mathrm{kDa}$ and higher, likely representing various levels of avidin attachment, whereas no band is detectable for the cells incubated at $37^{\circ} \mathrm{C}$. Molecular weight markers are in kilodaltons.

Table 3. Biophysical parameters of sodium currents expressed by $\mathrm{Na}_{\mathrm{v}} 1.2$ alone or $\mathrm{Na}_{\mathrm{v}} 1.2$ coexpressed with $\beta 1 \mathrm{WT}$ or $\mathrm{R} 125 \mathrm{C}$ in Xenopus oocytes

\begin{tabular}{|c|c|c|c|}
\hline & $\mathrm{Na}_{\mathrm{v}} 1.2$ & $\mathrm{Na}_{\mathrm{v}} 1.2+\beta 1 \mathrm{WT}$ & $\mathrm{Na}_{\mathrm{v}} 1.2+\mathrm{p} . \mathrm{R} 125 \mathrm{C}$ \\
\hline \multicolumn{4}{|l|}{$\begin{array}{l}\text { Voltage dependence } \\
\text { of activation }\end{array}$} \\
\hline$V_{1 / 2}(\mathrm{mV})$ & $-18.81 \pm 1.38$ & $-20.06 \pm 3.08$ & $-16.81 \pm 1.29$ \\
\hline$k$ & $-6.88 \pm 0.31$ & $-7.8 \pm 0.18$ & $-8.59 \pm 0.51$ \\
\hline$n$ & 10 & 7 & 13 \\
\hline \multicolumn{4}{|l|}{$\begin{array}{l}\text { Voltage dependence } \\
\text { of inactivation }\end{array}$} \\
\hline$V_{1 / 2}(\mathrm{mV})$ & $-51.69 \pm 2.60$ & $-58.11 \pm 1.33$ & $-58.17 \pm 1.41$ \\
\hline$k$ & $10.12 \pm 0.31$ & $7.18 \pm 0.49^{*}$ & $6.61 \pm 0.28^{*}$ \\
\hline$c$ & $-0.01 \pm 0.00$ & $-0.02 \pm 0.00$ & $0.01 \pm 0.01$ \\
\hline$n$ & 10 & 9 & 14 \\
\hline \multicolumn{4}{|l|}{ Kinetics of inactivation } \\
\hline$\tau_{\text {slow }}(\mathrm{ms})$ & $7.41 \pm 0.68$ & $5.10 \pm 0.50$ & $6.05 \pm 0.72$ \\
\hline Amplitude $_{\text {slow }}(\%)$ & $46.42 \pm 3.09$ & $10.10 \pm 1.29^{*}$ & $20.71 \pm 1.44^{*}$ \\
\hline$\tau_{\text {fast }}(\mathrm{ms})$ & $1.43 \pm 0.31$ & $0.49 \pm 0.04^{*}$ & $0.68 \pm 0.05^{*}$ \\
\hline Amplitude $_{\text {fast }}(\%)$ & $53.57 \pm 3.1$ & $89.89 \pm 2^{*}$ & $79.28 \pm 2.11^{*}$ \\
\hline$n$ & 10 & 6 & 9 \\
\hline
\end{tabular}

Data are mean \pm SEM. ${ }^{*} p \leq 0.001$ compared with $\mathrm{Na}_{v} 1.2$.

that, although p.R125C is inefficiently expressed at the cell surface at physiological temperatures in mammalian cells, if this trafficking defect could be overcome, the mutant subunit would be fully capable of modulating sodium current.

\section{Seizure susceptibility of mice expressing a single wild-type} Scn $1 b$ allele

$S c n 1 b^{-1-}$ mice have been described previously by our laboratory (Chen et al., 2004). These mice are born normally but then exhibit spontaneous generalized seizures beginning in the second postnatal week and exhibit other neurological abnormalities, including ataxia, characteristics that are similar to Dravet syndrome patients. Scn $1 b^{-/-}$mice die in adolescence by $\mathrm{P} 21$, recapitulating the small proportion of Dravet syndrome patients that die as a consequence of the disease. In contrast, $S c n 1 b^{+/-}$mice do not exhibit spontaneous behavioral seizures and live normal lifespans, suggestin ${ }^{1} g$ that the presence of a single wild-type $S c n 1 b$ allele is sufficient for normal sodium current modulation by $\beta 1$ in vivo. We demonstrate above that a SCN1B
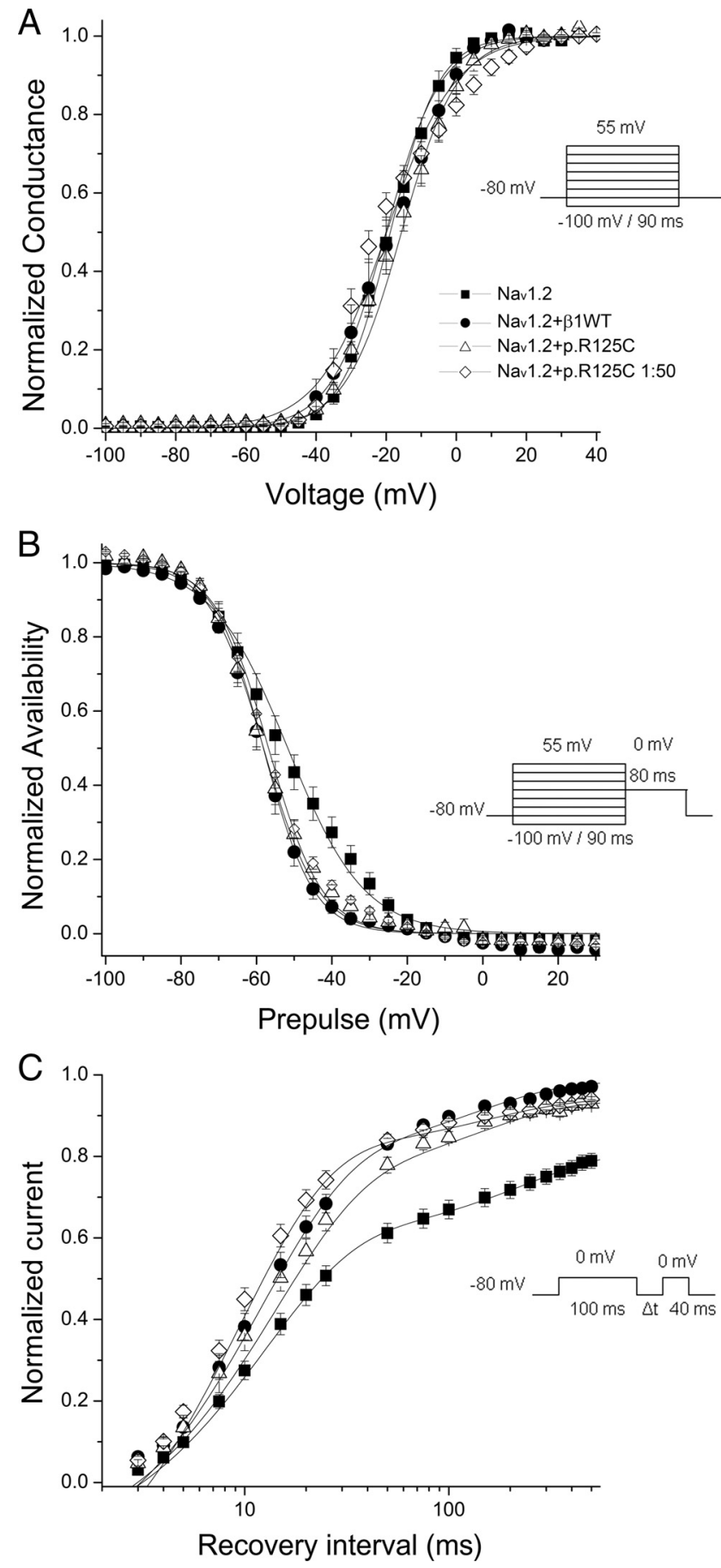

Figure 6. p.R125C modulates sodium currents expressed by $\mathrm{Na}_{\mathrm{v}} 1.2$ in Xenopus 00 cytes. Xenopus laevis oocytes were injected with the cRNA encoding $\mathrm{Na}_{\mathrm{v}} 1.2$ alone (filled squares), with $\beta 1$ WT (filled circles), or with p.R125C (open triangles). The p.R125C mRNA was also diluted 1:50 before injection (open diamonds). Neither $\beta 1$ WT nor p.R125C had any measurable effect on the voltage dependence of activation of $\mathrm{Na}_{v} 1.2 . A-C, p . R 125 \mathrm{C}$ $(\boldsymbol{A})$ modulates the voltage dependence of inactivation $(\boldsymbol{B})$ and rate of recovery from inactivation $(\boldsymbol{C})$ of $\mathrm{Na}_{\mathrm{v}} 1.2$ currents similar to $\beta 1$ WT. Insets show protocol schemes. Data points represent mean \pm SEM. Solid lines represent fits to the means. Biophysical properties are provided in Table 3.

Dravet syndrome mutant, p.R125C, is inefficiently trafficked to the cell surface in transfected mammalian cells at physiological temperatures, resulting in functional $S C N 1 B$ gene inactivation. Unlike previously described GEFS +1 patients carrying a single mutant SCN1B allele (Scheffer et al., 2007), the patient 


\begin{tabular}{|c|c|c|c|}
\hline Parameter & $\begin{array}{l}\text { Pentylenetetrazole } \\
\text { dose }(\mathrm{mg} / \mathrm{kg})\end{array}$ & $\operatorname{sen} 1 b^{+/+}$ & $\operatorname{Sen} 1 b^{+/-}$ \\
\hline \multicolumn{4}{|c|}{ Time to myoclonic jerk or seizure of } \\
\hline Highest seizure level $l^{b, c}$ & 60 & $6(3.68-6.56)$ & $6(3.03-6.46)$ \\
\hline Time to death (min) & 80 & $4.92 \pm 1.67$ & $11.36 \pm 3.26$ \\
\hline$n^{d}$ & & 8 & 8 \\
\hline
\end{tabular}

${ }^{a}$ Data are mean \pm SEM.

${ }^{b}$ Data are median ( $95 \%$ confidence interval).

'As measured using the modified Racine scale: 0 , no seizure; 1 , staring/unresponsive; 2 , focal clonic convulsion (including head nod, twitch, myoclonic jerk, backing); 3 , forelimb clonus (tonic-clonic seizure); 4 , rearing; 5 , loss of posture (including jumping, rearing, and falling); 6 , status epilepticus and death.

${ }^{d}$ Eight mice of each genotype used for each dose.

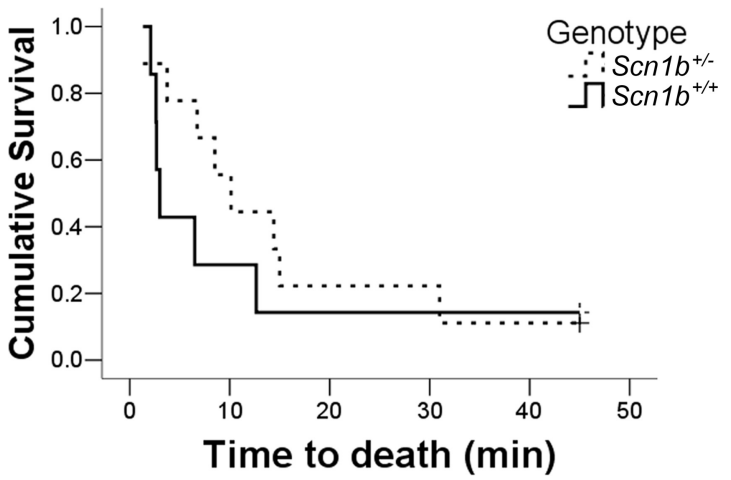

Figure 7. Time to death attributable to status epilepticus of $S \mathrm{Cn} 1 b^{+/-}$mice is similar to $S \mathrm{Sn} 1 b^{+/+}$mice. Mice with either one $\left(\mathrm{Scn} 1 b^{+/-}\right)$or two $\left(S_{\mathrm{cn}} 1 b^{+/+}\right)$copies of $S \mathrm{Cn} 1 b$ were injected with PTZ to induce seizures. After a dose of $80 \mathrm{mg} / \mathrm{kg}$, the majority of mice died as a consequence of status epilepticus. Cumulative survival curves show no significant differences between $\operatorname{Scn} 1 b^{+/-}$mice (broken line; $n=8$ ) and $\operatorname{Scn} 1 b^{+/+}$mice (solid line; $n=8$ ). $p=$ $0.383, \log$-rank test.

described in our study is homozygous for the p.R125C mutation. Thus, based on our heterologous expression data, we predict that this Dravet syndrome patient had a functional SCN1B null phenotype. Both parents of this patient are heterozygous for the mutation and do not exhibit seizures, similar to Scn $1 b^{+/-}$mice (Chen et al., 2004). To investigate whether patients carrying one mutant $S C N 1 B$ allele might be more susceptible to seizure induction in response to proconvulsive stimuli, we injected $S c n 1 b^{+/-}$and $S c n 1 b^{+/+}$littermates with the GABA antagonist PTZ at age P18-P21, the time interval during which the seizures observed in $S c n 1 b^{-1-}$ mice are at their most severe. $S c n 1 b^{+/-}$and $S c n 1 b^{+/+}$mice were injected with a single dose of PTZ between 20 and $80 \mathrm{mg} / \mathrm{kg}$, and the resulting seizures were graded according to the modified Racine scale (Racine, 1972; Cole et al., 2000), described in the legend to Table 4 . At $20 \mathrm{mg} / \mathrm{kg}$, we observed minor changes in the level of activity of mice of both genotypes, whereas at $40 \mathrm{mg} / \mathrm{kg}$, a minority of mice from both groups exhibited myoclonic jerks and forelimb clonus. At $60 \mathrm{mg} / \mathrm{kg}$, the majority of mice from both groups exhibited seizures between grades 2 and 6 . At this dose, there were no statistically significant differences in the mean time to myoclonic jerk or seizures of higher severity between $S c n 1 b^{+/-}$ and $S c n 1 b^{+/+}$mice (Table 4). Also, at $60 \mathrm{mg} / \mathrm{kg}$, there were no significant differences in the highest seizure level reached by each genotype (Table 4). At a dose of $80 \mathrm{mg} / \mathrm{kg}, 85 \%$ of $S \mathrm{cn} 1 b^{+/+}$and $90 \%$ of $S \mathrm{Cn} 1 b^{+/-}$died during status epilepticus. There were no statistical differences in the mean time to death between the two groups (Table 4) or cumulative survival (Fig. 7). Although not
Table 5. Analysis of evoked action potentials in CA1 or CA3 hippocampal slices from $\operatorname{Scn} 1 b^{+/+}$and $\operatorname{Sen} 1 b^{-/-}$mice

\begin{tabular}{|c|c|c|}
\hline & $\operatorname{Sen} 1 b^{+/+}$ & $\operatorname{Sen} 1 b^{-1-}$ \\
\hline \multicolumn{3}{|l|}{ CA1 } \\
\hline Resting potential (mV) & $-71.99 \pm 1.21$ & $-71.78 \pm 0.76$ \\
\hline Input resistance $(\mathrm{M} \Omega$ ) & $142.60 \pm 27.68$ & $141.36 \pm 11.23$ \\
\hline Threshold (mV) & $-33.81 \pm 2.00$ & $-33.00 \pm 1.50$ \\
\hline Rise time (ms) & $0.76 \pm 0.03$ & $0.67 \pm 0.03$ \\
\hline Peak voltage (mV) & $35.48 \pm 1.91$ & $33.73 \pm 2.16$ \\
\hline Amplitude (mV) & $69.29 \pm 2.90$ & $66.74 \pm 2.36$ \\
\hline$n$ & 22 & 19 \\
\hline \multicolumn{3}{|l|}{$\mathrm{CA} 3$} \\
\hline Resting potential (mV) & $-72.96 \pm 0.54$ & $-71.74 \pm 0.59$ \\
\hline Input resistance $(\mathrm{M} \Omega$ ) & $156.99 \pm 5.97$ & $161.75 \pm 11.06$ \\
\hline Threshold (mV) & $-33.82 \pm 0.75$ & $-35.73 \pm 0.78$ \\
\hline Rise time (ms) & $0.61 \pm 0.02$ & $0.52 \pm 0.01$ \\
\hline Peak voltage (mV) & $38.77 \pm 1.49$ & $46.36 \pm 1.21^{*}$ \\
\hline Amplitude (mV) & $72.59 \pm 1.60$ & $82.10 \pm 1.29^{\dagger}$ \\
\hline$n$ & 34 & 21 \\
\hline
\end{tabular}

significant, trends in the data suggest that $S c n 1 b^{+/-}$mice may be even less sensitive to PTZ seizure induction than their wildtype littermates. Throughout these experiments, control animals were injected with vehicle alone ( $0.9 \%$ saline solution); none of these animals exhibited seizures.

\section{$S c n 1 b^{-/-}$mice show altered electrical excitability in CA3 but} not CA1 regions of the hippocampus

Hippocampal pyramidal neurons acutely isolated from $S c n 1 b^{-/-}$ mice have normal sodium currents (Chen et al., 2004). To explore potential differences in electrical excitability by which a loss of functional expression of $\beta 1$ may result in seizures, we performed recordings from acutely isolated hippocampal slices, a preparation in which synaptic contacts remain intact. Because Scn $1 b^{-1-}$ mice exhibit differential expression of $\mathrm{Na}_{\mathrm{v}} 1.1$ and $\mathrm{Na}_{\mathrm{v}} 1.3$ in the CA3 but not in the CA1 region of the hippocampus (Chen et al., 2004), we analyzed APs in both regions. As shown in Table 5, we did not observe significant differences in the excitability of $S c n 1 b^{-/-}$CA1 neurons compared with wild type. Measurements included the neuronal resting membrane potential, input resistance, $\mathrm{AP}$ threshold, AP rise time, AP peak voltage, and AP amplitude. In contrast, we observed that $S c n 1 b^{-/-}$CA3 neurons fired evoked APs with a significantly higher peak voltage and significantly greater amplitude compared with wild type. The differences in AP rise time for CA3 neurons between the two genotypes approached significance $(p=0.051)$. Thus, the absence of functional $\beta 1$ subunits is predicted to result in CA3 neuronal hyperexcitability in vivo, consistent with the severe seizure phenotype of $S c n 1 b^{-/-}$mice as well as the severe seizure phenotype of the pediatric patient in this study.

\section{Sodium current density in $S c n 1 b^{-/-}$CA3 bipolar neurons is similar to wild type}

$S c n 1 a^{+/-}$mice recapitulate the phenotype of Dravet syndrome patients with SCN1A mutations. The mechanism of epileptogenesis in $\mathrm{Scn}_{1 \mathrm{a}^{+/-}}$mice includes a substantial reduction in sodium current density of hippocampal bipolar, but not pyramidal, neurons (Yu et al., 2006). We showed previously that hippocampal pyramidal neurons acutely isolated from $S c n 1 b^{-/-}$mice have normal sodium currents compared with their wild-type littermates (Chen et al., 2004). To explore whether the changes in CA3 hyperexcitability observed in hippocampal slice recordings re- 


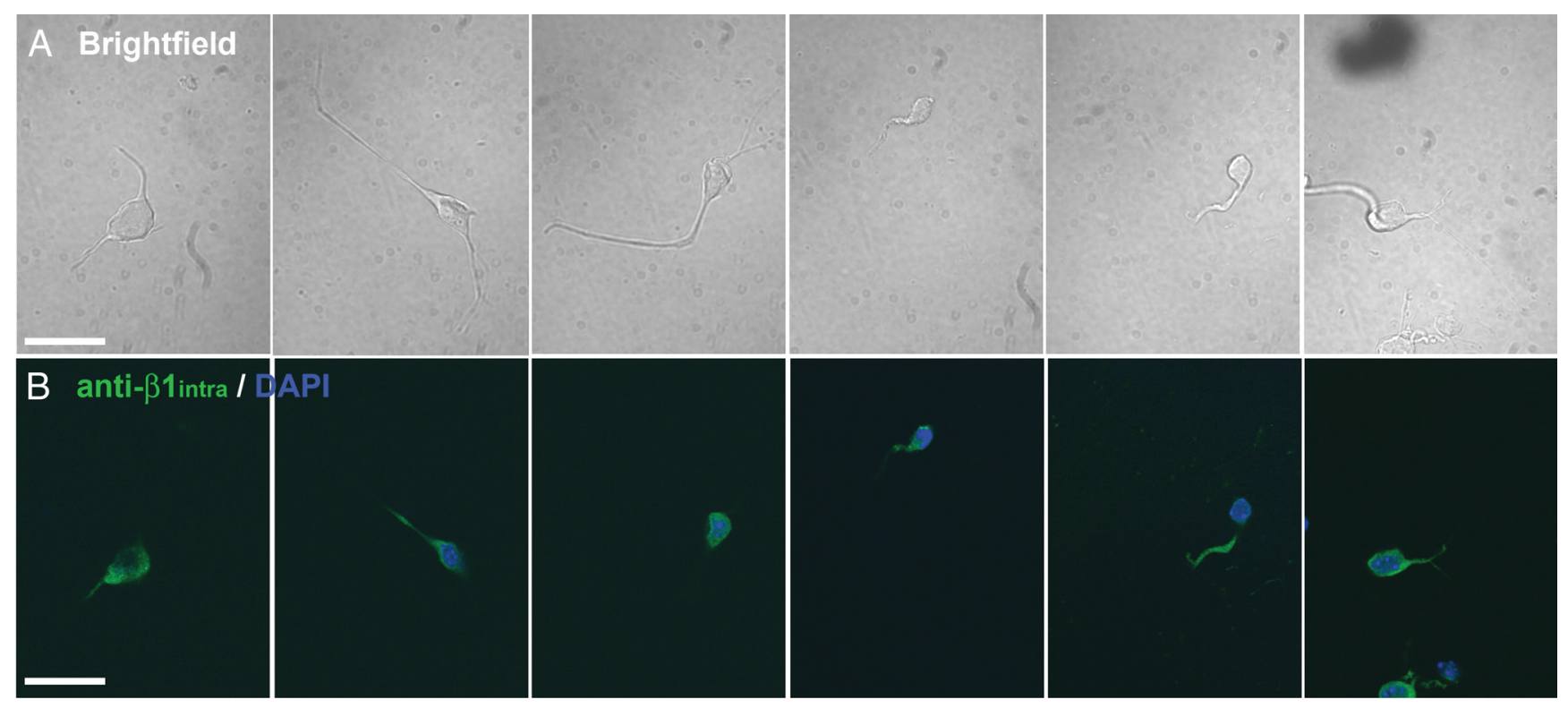

Figure 8. $\quad \beta 1$ is expressed in hippocampal CA3 bipolar neurons. Acutely dissociated hippocampal CA3 bipolar neurons from P10 Scn $1 b^{+/+}$mice were fixed with $4 \%$ paraformaldehyde and stained for $\beta 1$ using anti- $\beta 1_{\text {intra }}$ antibody. A, Bright-field images. $B$, Anti- $\beta 1_{\text {intra }}$ green; DAPI, blue. Scale bars, $20 \mu \mathrm{m}$.

sulted from a similar mechanism as described for $\operatorname{Scn} 1 a^{+/-}$mice, we recorded sodium currents in bipolar neurons. We first documented the expression of $\beta 1$ subunits in acutely dissociated CA3 bipolar neurons from $S c n 1 b^{+/+}$mice by staining with anti$\beta 1_{\text {intra }}$. All of the bipolar neurons examined were positive for the presence of $\beta 1$ in the cell body, with the majority of neurons also exhibiting $\beta 1$ in their processes (Fig. 8). We then recorded peak sodium current density elicited in acutely isolated CA3 hippocampal bipolar neurons after a test pulse to $-20 \mathrm{mV}$ from a holding potential of $-80 \mathrm{mV}$, using the whole-cell patch-clamp technique. In contrast to the study by Yu et al. (2006), we observed no significant differences in peak sodium current density between genotypes $\left(\operatorname{Scn} 1 b^{-/-}\right.$mice, $-87.24 \pm 13.44 \mathrm{pA} / \mathrm{pF}, n=$ $17 ; S_{c n} 1 b^{+/+}$littermates, $-58.21 \pm 9.99 \mathrm{pA} / \mathrm{pF}, n=9 ; p=0.159$, Student's $t$ test). Similarly, there were no measurable differences in the capacitance $\left(S c n 1 b^{-/-}, 10.73 \pm 1.14 \mathrm{pF}, n=17 ; S_{c} n 1 b^{+/+}\right.$ littermates, $13.37 \pm 1.13 \mathrm{pF}, n=9 ; p=0.152$, Student's $t$ test), the voltage dependence of activation $\left(S c n 1 b^{-/-},-45.00 \pm 2.20\right.$ $\mathrm{mV}, n=4 ; S_{c n} 1 b^{+/+}$littermates, $-42.34 \pm 0.46 \mathrm{mV}, n=4 ; p=$ 0.28 , Student's $t$ test), or voltage dependence of inactivation $\left(S c n 1 b^{-/-},-58.00 \pm 1.26 \mathrm{mV}, n=4 ; S c n 1 b^{+/+}\right.$littermates, $-61.22 \pm 2.28 \mathrm{mV}, n=4 ; p=0.26$, Student's $t$ test) of bipolar cells between the two genotypes. Thus, although the phenotypes of $S c n 1 a^{+/-}$and $S c n 1 b^{-/-}$mice are remarkably similar, the mechanisms of epileptogenesis are different in these two models.

\section{Discussion}

In the present study, we demonstrate for the first time a homozygous loss-of-function mutation in SCN1B responsible for Dravet syndrome, an epilepsy syndrome in the most severe range of the GEFS + spectrum. SCN1B p.R125C results in $\beta 1$ subunit polypeptides that are synthesized normally but not transported to the cell surface in mammalian fibroblasts in vitro. Because the patient in our study carried two mutant $S C N 1 B$ alleles, our data predict a complete loss of $\beta 1$ function, resulting in a null phenotype. Trafficking of p.R125C is rescued at nonphysiological temperatures in mammalian cells, and p.R125C exhibits normal channel modulation in Xenopus oocytes, a heterologous system that is maintained at $18^{\circ} \mathrm{C}$. The seizure susceptibility to adminis- tration of PTZ in $S c n 1 b^{+/-}$mice was not significantly different from wild type. Slice recordings from $S c n 1 b^{-1-}$ hippocampus showed increased excitability in CA3 but not CA1 neurons. In contrast to the $S c n 1 a^{+/-}$model of Dravet syndrome (Yu et al., 2006), we did not measure significant differences in sodium current density in $\mathrm{Scn} 1 b^{-/-}$CA3 bipolar neurons. We conclude that one $S C N 1 B$ allele is sufficient for the maintenance of normal electrical excitability in brain, whereas the SCN1B null phenotype results in hyperexcitability, in both mice and humans. These results predict that future therapeutic interventions for patients carrying trafficking mutations in SCN1B may include small molecule chaperones, similar to those being developed for cystic fibrosis, afibrinogenemia, and $\alpha 1$-antitrypsin deficiency (Amaral, 2006; Gregersen, 2006; Vu et al., 2008).

Inherited as well as de novo mutations of ion channel genes result in several different types of epilepsy. Mutations in SCN1B are linked to GEFS + 1, a syndrome that displays multiple seizure types in different families, and even within single individuals, bearing the mutated channel subunit (Wallace et al., 1998, 2002; Audenaert et al., 2003; Scheffer et al., 2007). Epilepsy syndromes in GEFS + families include febrile seizures, febrile seizures plus, mild generalized epilepsies, severe epileptic encephalopathies, including myoclonic-astatic epilepsy and Dravet syndrome, temporal lobe epilepsy, and frontal lobe epilepsy (Scheffer et al., 2007). Subsequently, the diverse seizure pattern of GEFS + has also been identified in families bearing mutations in SCN1A, encoding $\mathrm{Na}_{\mathrm{v}} 1.1$ (Escayg et al., 2000, 2001; Wallace et al., 2001b), as well as in GABRG2, encoding the $\gamma 2$ subunit of the $\mathrm{GABA}_{\mathrm{A}}$ receptor (Baulac et al., 2001; Wallace et al., 2001a; Harkin et al., 2002). These findings have challenged the idea that a defined mutation of a single ion channel gene results in a uniform seizure type and suggest that $\mathrm{Na}_{\mathrm{v}} 1.1$, sodium channel $\beta 1$, and $\mathrm{GABA}_{\mathrm{A}}$ receptors may be functionally linked. Furthermore, mutations in any of the genes encoding these proteins can result in GEFS + spectrum diseases through disruption of inhibitory neuronal excitability.

More than 250 mutations in SCN1A are associated with Dravet syndrome (Burgess, 2005; Meisler and Kearney, 2005; 
Table 6. Characteristics of SCN1B mutants associated with epilepsy

\begin{tabular}{|c|c|c|c|c|}
\hline Mutation & $\begin{array}{l}\text { Heterologous } \\
\text { system }\end{array}$ & $\begin{array}{l}\operatorname{VGSC}^{a} \alpha \text { subunit } \\
\text { tested }\end{array}$ & Results & Reference \\
\hline \multirow[t]{6}{*}{ p.C121W } & Xenopus oocytes & $\mathrm{Na}_{\mathrm{v}} 1.2$ & $\begin{array}{l}\text { Similar functional modulation of } \alpha \text { when injected at high concentration. Decreased modulation } \\
\text { at lower concentration. }{ }^{b}\end{array}$ & Meadows et al., 2002 \\
\hline & 1610 cells & $\mathrm{Na}_{\mathrm{v}} 1.3$ & $\begin{array}{l}\text { Association with } \alpha \text {. No shift in voltage dependence of current inactivation. Decreased frequency- } \\
\text { dependent rundown. Acceleration of recovery from fast inactivation. }{ }^{b} \text { No dominant-negative } \\
\text { effect. }\end{array}$ & Meadows et al., 2002 \\
\hline & 1610 cells & $\mathrm{Na}_{\mathrm{v}} 1.2$ & $\begin{array}{l}\text { Association with } \alpha \text {. No shift in voltage dependence of current inactivation. No decrease in } \\
\text { frequency-dependent rundown. Acceleration of recovery from fast inactivation. }{ }^{b} \text { Equally } \\
\text { effective as WT in promoting cell surface expression of } \alpha \text { subunits. }^{b}\end{array}$ & Meadows et al., 2002 \\
\hline & HEK-293 cells & $\mathrm{Na}_{v} 1.4$ & $\begin{array}{l}\text { Equally effective as wild type in promoting cell surface expression of } \alpha \text { subunits. }^{b} \\
\text { Unable to accelerate recovery from inactivation. }{ }^{a}\end{array}$ & Tammaro et al., 2002 \\
\hline & & & $\begin{array}{l}\text { Channels containing p.C121W may require larger-than-normal stimuli to open but, once } \\
\text { activated, inactivate considerably less readily than channels containing wild-type } \beta 1 \text {. }\end{array}$ & Aman et al., 2009 \\
\hline & HEK-293 cells & $\mathrm{Na}_{\mathrm{v}} 1.1$ & & \\
\hline p.I70-E74del & $\mathrm{N} / \mathrm{A}$ & $\mathrm{N} / \mathrm{A}$ & N/A & Audenaert et al., 2003 \\
\hline p.R85C & HEK-293 cells & $\mathrm{Na}_{\mathrm{v}} 1.2$ & $\begin{array}{l}\text { No modulation of current density. } \\
\text { Inability to shift voltage dependence of fast activation, fast or slow inactivation, decrease time } \\
\text { constant of fast inactivation, or accelerate recovery from fast inactivation. }{ }^{b} \text { No protein } \\
\text { expression detected. } .^{b}\end{array}$ & Xu et al., 2007 \\
\hline p.R85H & HEK-293 cells & $\mathrm{Na}_{\mathrm{v}} 1.2$ & $\begin{array}{l}\text { No modulation of current density. Inability to shift voltage dependence of fast activation or } \\
\text { inactivation or accelerate recovery from fast inactivation. }{ }^{b} \text { No protein expression detected. }\end{array}$ & Xu et al., 2007 \\
\hline \multirow[t]{3}{*}{ p.R125C } & HEK-293 cells & $\mathrm{Na}_{\mathrm{v}} 1.1$ & Reduced cell surface expression. ${ }^{b}$ & Present paper \\
\hline & 1610 cells & $\mathrm{Na}_{\mathrm{v}} 1.2$ & $\begin{array}{l}\text { Decreased sodium current density. }{ }^{b} \text { Inability to shift voltage dependence of inactivation. } \\
\text { Reduced frequency-dependent rundown, accelerated recovery from fast inactivation, } \\
\text { increased persistent current. }{ }^{b} \text { Reduced cell surface expression. }{ }^{b}\end{array}$ & Present paper \\
\hline & Xenopus oocytes & $\mathrm{Na}_{\mathrm{v}} 1.2$ & Channel modulation similar to wild type. & Present paper \\
\hline
\end{tabular}

${ }^{a}$ Voltage-gated sodium channel.

${ }^{b}$ Compared with $\beta 1$ WT.

Turnbull et al., 2005; Lossin, 2009), with many of these mutations resulting in SCN1A haploinsufficiency. Scn1a ${ }^{+/-}$mice, which express half the normal complement of $\mathrm{Na}_{\mathrm{v}} 1.1$ channels (Yu et al., 2006), and knock-in mice, which carry the p.R1407X mutation, found in some patients of Dravet Syndrome (Ogiwara et al., 2007) are animal models of this disease. $S c n 1 a^{+/-}$mice display spontaneous seizures and sporadic deaths beginning after P21. Scn $1 a^{-/-}$mice develop ataxia and seizures beginning at P9 and die by P15. The loss of Scn1a has no measurable effects on sodium currents in isolated hippocampal pyramidal (excitatory) neurons. However, GABAergic inhibitory bipolar neurons isolated from both $\operatorname{Scn} 1 a^{-1-}$ and $S c n 1 a^{+/-}$mice have significantly reduced sodium current density (Yu et al., 2006). Scn $1 a^{R X / R X}$ mice develop ataxia and seizures during the second postnatal week and die by P20. $S c n 1 a^{R X /+}$ mice exhibit seizures from the third postnatal week and increased mortality thereafter, most probably as a consequence of status epilepticus. The $S c n 1 a^{R X /+}$ mice also exhibit electrophysiological abnormalities of inhibitory cortical interneurons that are positive for parvalbumin. In these neurons, the membrane potential is more negative, and there is a progressive decrement in spike amplitude during prolonged spike trains (Ogiwara et al., 2007). The behavioral and molecular phenotypes of $S_{c n} 1 a^{-/-}, S_{c n} 1 a^{+/-}, S_{c n} 1 a^{R X / R X}$, and $S_{c n} 1 a^{R X /+}$ mice are similar to that of $S c n 1 b^{-/-}$mice, which develop generalized seizures and ataxia beginning at approximately P10 and die by P21 (Chen et al., 2004). The mechanisms of neuronal hyperexcitability between these models, however, appear to be different, because we did not detect reductions in bipolar neuron sodium current density in $S c n 1 b^{-/-}$mice, as described for Scn $1 a^{+/-}$neurons (Yu et al., 2006). Nevertheless, consistent with a functional link between $S c n 1 a$ and $S c n 1 b, S c n 1 b$ mice have significantly reduced $\mathrm{Na}_{\mathrm{v}} 1.1$ expression in the hippocampus (Chen et al., 2004), suggesting that $S c n 1 a$ and $S c n 1 b$ may be critical partners in the regulation of hippocampal excitability. Elucidation of the mechanism causing Dravet syndrome-like seizures in $S c n 1 b^{-/-}$mice will require a more detailed investigation in the future. Possible insights into this problem may be gleaned from our recent work with $\mathrm{Na}_{\mathrm{v}} 1.1$ expressed in a heterologous system, suggesting that $\beta 1$ plays a dominant role in reducing sodium channel activity (Aman et al., 2009). These results raise the possibility that disruption of $\beta 1$ in inherited epilepsies may slow inactivation rates in some neurons and thus contribute to the excessive firing associated with seizure disorders.

A mutation in SCN1A identified in a family with dominantly inherited GEFS + further illustrates the importance of $\mathrm{Na}_{\mathrm{v}} 1.1-\beta 1$ interactions in the regulation of electrical excitability in brain (Spampanato et al., 2004). The mutation D1866Y alters a conserved aspartate residue in the $\mathrm{C}$ terminus of $\mathrm{Na}_{\mathrm{v}} 1.1$, resulting in decreased modulation of $\mathrm{Na}_{\mathrm{v}} 1.1$ by $\beta 1$. Coimmunoprecipitation from transfected mammalian cells confirmed the interaction between the $\mathrm{C}$ termini of wild-type $\mathrm{Na}_{\mathrm{v}} 1.1$ and $\beta 1$. The $\mathrm{Na}_{\mathrm{v}} 1.1$ D1866Y mutation weakens this interaction, demonstrating a novel molecular mechanism involving $\alpha-\beta 1$ association, leading to seizure susceptibility and adding support to the hypothesis that SCN1A and SCN1B are functionally linked in the molecular basis of epilepsy.

Mutations (p.C121W, p.I70_E74del, p.R85C, and p.R85H) (Table 6) in SCN1B cause GEFS + 1 epilepsy (Wallace et al., 1998, 2002; Audenaert et al., 2003; Scheffer et al., 2007). Interestingly, all of these mutations are located within the extracellular Ig loop domain, suggesting that $\beta 1$-mediated cell adhesion is clinically relevant. We showed previously that, compared with wild type, p.C121W increases the fraction of available sodium channels at resting membrane potentials and reduces sodium current rundown during high-frequency channel activity (Meadows et al., 2002). The p.C121W mutation also disrupts $\beta 1$-mediated ho- 
mophilic cell-cell adhesion. Although its precise mechanism in neurons is not understood, it is generally agreed that p.C121W produces a nonfunctional $\beta 1$ subunit (Avanzini et al., 2007). We demonstrated recently that sodium channel complexes containing p.C121W may require larger-than-normal stimuli to open but, once activated, inactivate considerably less readily than channels containing wild-type $\beta 1$, a feature that may promote repetitive firing and lead to hyperexcitability (Aman et al., 2009). Similar to p.R125C, p.R85C and p.R85H are not detectable at the cell surface in vitro, although $\mathrm{p} . \mathrm{R} 85 \mathrm{H}$ appeared to modulate the voltage dependence of sodium channel slow inactivation without any effect on other electrophysiological parameters. p.R85C had no detectable effects on any channel property measured, suggesting that, similar to p.R125C, this mutant $\beta 1$ subunit polypeptide may not be expressed at the cell surface (Xu et al., 2007). The p.I70_E74del mutant has not been tested functionally.

With the exception of the present report, all mutations responsible for the GEFS + spectrum of epilepsies to date have been found to be autosomal dominant, with patients expressing one mutant and one wild-type allele. To our knowledge, this is the first report of a $S C N 1 B$ mutation that extends the range of GEFS + phenotypes to the most severe side of the spectrum as well as the first report of an autosomal recessive mutation resulting in a GEFS + spectrum disease. Given that our proband was homozygous for the mutation and his parents are heterozygous and healthy, it is unlikely that p.R125C functions as a dominant negative. The parental phenotypes recapitulate the situation observed in mice in which animals carrying the $S c n 1 b$ null mutation seize spontaneously, whereas animals with only one wild-type $S c n 1 b$ allele appear to be neurologically normal. Like $S c n 1 a^{+/-}$ and $S c n 1 a^{\mathrm{RX} /+}$ mice, the epileptic phenotype of $S_{c n} 1 b^{-/-}$mice has similarities to that observed in Dravet syndrome patients. All are normal at birth and then begin exhibiting seizures during infancy that gain in intensity. However, although seizures in patients tend to be preceded by a triggering event, e.g., fever or vaccination, they occur spontaneously in the mice. Nevertheless, patients eventually develop spontaneous seizures, which also mark the beginning of rapid disease progression. Scn $1 a^{+/-}$, $\operatorname{Scn} 1 a^{R X / R X}$, and $S c n 1 b^{-/-}$mice also exhibit an ataxic gait, similar to many Dravet syndrome patients (Chen et al., 2004; Yu et al., 2006; Ogiwara et al., 2007). Thus, Scn $1 a^{+/-}, S_{c n} 1 a^{R X /+}$, and $S c n 1 b^{-1-}$ mice may represent animal models of Dravet syndrome. However, in contrast to Scn1a, in which haploinsufficiency results in a severe epileptic phenotype, the functional loss of both $S c n 1 b$ alleles is required for disease. We propose that one wild-type copy of $S c n 1 b$ is sufficient for normal control of excitability in the brain.

In summary, we present the first case of Dravet syndrome attributable to a homozygous mutation in SCN1B and show that the consequence of this mutation is the inability of $\beta 1$ polypeptides to be trafficked to the surface of transfected mammalian cells. Although HEK-293 and 1610 cells certainly do not fully recapitulate the situation in neurons, our data predict that the patient carrying this mutation was a functional $S C N 1 B$ null and that $S c n 1 b^{-/-}$mice may be a model for Dravet syndrome. The present results from hippocampal slice recordings as well as previous results from $S c n 1 b^{-/-}$mice (Brackenbury et al., 2008b) predict that not only deficits in excitability but abnormal cell adhesion resulting in aberrant neuronal pathfinding and fasciculation may play a role in this epileptic syndrome.

\section{References}

Aman TK, Grieco-Calub TM, Chen C, Rusconi R, Slat EA, Isom LL, Raman IM (2009) Regulation of persistent Na current by interactions between beta subunits of voltage-gated Na channels. J Neurosci 29:2027-2042.

Amaral MD (2006) Therapy through chaperones: sense or antisense? Cystic fibrosis as a model disease. J Inherit Metab Dis 29:477-487.

Audenaert D, Claes L, Ceulemans B, Löfgren A, Van Broeckhoven C, De Jonghe $\mathrm{P}$ (2003) A deletion in SCN1B is associated with febrile seizures and early-onset absence epilepsy. Neurology 61:854-856.

Avanzini G, Franceschetti S, Mantegazza M (2007) Epileptogenic channelopathies: experimental models of human pathologies. Epilepsia 48 [Suppl 2]:51-64.

Baulac S, Huberfeld G, Gourfinkel-An I, Mitropoulou G, Beranger A, Prud'homme JF, Baulac M, Brice A, Bruzzone R, LeGuern E (2001) First genetic evidence of GABA(A) receptor dysfunction in epilepsy: a mutation in the gamma2-subunit gene. Nat Genet 28:46-48.

Brackenbury WJ, Isom LL (2008) Voltage-gated $\mathrm{Na}+$ channels: potential for beta subunits as therapeutic targets. Expert Opin Ther Targets 12:1191-1203.

Brackenbury WJ, Djamgoz MB, Isom LL (2008a) An emerging role for voltage-gated $\mathrm{Na}^{+}$channels in cellular migration: regulation of central nervous system development and potentiation of invasive cancers. Neuroscientist 14:571-583.

Brackenbury WJ, Davis TH, Chen C, Slat EA, Detrow MJ, Dickendesher TL, Ranscht B, Isom LL (2008b) Voltage-gated $\mathrm{Na}^{+}$channel $\beta 1$ subunitmediated neurite outgrowth requires Fyn kinase and contributes to postnatal CNS development in vivo. J Neurosci 28:3246-3256.

Burgess DL (2005) Neonatal epilepsy syndromes and GEFS+: mechanistic considerations. Epilepsia 46 [Suppl 10]:51-58.

Catterall WA (2000) From ionic currents to molecular mechanisms: the structure and function of voltage-gated sodium channels. Neuron 26:13-25.

Catterall WA, Goldin AL, Waxman SG (2005) International Union of Pharmacology. XLVII. Nomenclature and structure-function relationships of voltage-gated sodium channels. Pharmacol Rev 57:397-409.

Catterall WA, Dib-Hajj S, Meisler MH, Pietrobon D (2008) Inherited neuronal ion channelopathies: new windows on complex neurological diseases. J Neurosci 28:11768-11777.

Cestèle S, Scalmani P, Rusconi R, Terragni B, Franceschetti S, Mantegazza M (2008) Self-limited hyperexcitability: functional effect of a familial hemiplegic migraine mutation of the Navl.1 (SCN1A) $\mathrm{Na}^{+}$channel. J Neurosci 28:7273-7283.

Chen C, Westenbroek RE, Xu X, Edwards CA, Sorenson DR, Chen Y, McEwen DP, O’Malley HA, Bharucha V, Meadows LS, Knudsen GA, Vilaythong A, Noebels JL, Saunders TL, Scheuer T, Shrager P, Catterall WA, Isom LL (2004) Mice lacking sodium channel betal subunits display defects in neuronal excitability, sodium channel expression, and nodal architecture. J Neurosci 24:4030-4042

Chen C, Dickendesher TL, Oyama F, Miyazaki H, Nukina N, Isom LL (2007) Floxed allele for conditional inactivation of the voltage-gated sodium channel betal subunit Scn1b. Genesis 45:547-553.

Claes L, Del-Favero J, Ceulemans B, Lagae L, Van Broeckhoven C, De Jonghe P (2001) De novo mutations in the sodium-channel gene SCN1A cause severe myoclonic epilepsy of infancy. Am J Hum Genet 68:1327-1332.

Cole TB, Robbins CA, Wenzel HJ, Schwartzkroin PA, Palmiter RD (2000) Seizures and neuronal damage in mice lacking vesicular zinc. Epilepsy Res 39:153-169.

Davis TH, Chen C, Isom LL (2004) Sodium channel $\beta 1$ subunits promote neurite outgrowth in cerebellar granule neurons. J Biol Chem 279:51424-51432.

den Dunnen JT, Antonarakis SE (2001) Nomenclature for the description of human sequence variations. Hum Genet 109:121-124.

Dravet C, Bureau M, Oguni H, Fukuyama Y, Cokar O (2005) Severe myoclonic epilepsy in infancy: Dravet syndrome. Adv Neurol 95:71-102.

Escayg A, MacDonald BT, Meisler MH, Baulac S, Huberfeld G, AnGourfinkel I, Brice A, LeGuern E, Moulard B, Chaigne D, Buresi C, Malafosse A (2000) Mutations of SCN1A, encoding a neuronal sodium channel, in two families with GEFS+2. Nat Genet 24:343-345.

Escayg A, Heils A, MacDonald BT, Haug K, Sander T, Meisler MH (2001) A novel scnla mutation associated with generalized epilepsy with febrile 
seizures plus- and prevalence of various patients with epilepsy. Am J Hum Genet 68:866-873.

Fein AJ, Meadows LS, Chen C, Slat EA, Isom LL (2007) Cloning and expression of a zebrafish SCN1B ortholog and identification of a species-specific splice variant. BMC Genomics 8:226.

Fujiwara T (2006) Clinical spectrum of mutations in SCN1A gene: severe myoclonic epilepsy in infancy and related epilepsies. Epilepsy Res 70 [Suppl 1]:S223-S230.

Gennaro E, Veggiotti P, Malacarne M, Madia F, Cecconi M, Cardinali S, Cassetti A, Cecconi I, Bertini E, Bianchi A, Gobbi G, Zara F (2003) Familial severe myoclonic epilepsy of infancy: truncation of Nav1.1 and genetic heterogeneity. Epileptic Disord 5:21-25.

Gissen P, Maher ER (2007) Cargos and genes: insights into vesicular transport from inherited human disease. J Med Genet 44:545-555.

Gregersen N (2006) Protein misfolding disorders: pathogenesis and intervention. J Inherit Metab Dis 29:456-470.

Harkin LA, Bowser DN, Dibbens LM, Singh R, Phillips F, Wallace RH, Richards MC, Williams DA, Mulley JC, Berkovic SF, Scheffer IE, Petrou S (2002) Truncation of the GABA(A)-receptor gamma2 subunit in a family with generalized epilepsy with febrile seizures plus. Am J Hum Genet 70:530-536.

Isom LL, De Jongh KS, Patton DE, Reber BF, Offord J, Charbonneau H, Walsh K, Goldin AL, Catterall WA (1992) Primary structure and functional expression of the b1 subunit of the rat brain sodium channel. Science 256:839-842.

Isom LL, Scheuer T, Brownstein AB, Ragsdale DS, Murphy BJ, Catterall WA (1995) Functional co-expression of the b1 and type IIA a subunits of sodium channels in a mammalian cell line. J Biol Chem 270:3306-3312.

Kazen-Gillespie KA, Ragsdale DS, D'Andrea MR, Mattei LN, Rogers KE, Isom LL (2000) Cloning, localization, and functional expression of sodium channel b1A subunits. J Biol Chem 275:1079-1088.

Kearney JA, Wiste AK, Stephani U, Trudeau MM, Siegel A, RamachandranNair R, Elterman RD, Muhle H, Reinsdorf J, Shields WD, Meisler MH, Escayg A (2006) Recurrent de novo mutations of SCN1A in severe myoclonic epilepsy of infancy. Pediatr Neurol 34:116-120.

Korff CM, Nordli DR Jr (2006) Epilepsy syndromes in infancy. Pediatr Neurol 34:253-263.

Lopez-Santiago LF, Pertin M, Morisod X, Chen C, Hong S, Wiley J, Decosterd I, Isom LL (2006) Sodium channel $\beta 2$ subunits regulate tetrodotoxinsensitive sodium channels in small dorsal root ganglion neurons and modulate the response to pain. J Neurosci 26:7984-7994.

Lopez-Santiago LF, Meadows LS, Ernst SJ, Chen C, Malhotra JD, McEwen DP, Speelman A, Noebels JL, Maier SK, Lopatin AN, Isom LL (2007) Sodium channel Scn1b null mice exhibit prolonged QT and RR intervals. J Mol Cell Cardiol 43:636-647.

Lossin C (2009) A catalog of SCN1A variants. Brain Dev 31:114-130.

Malhotra JD, Kazen-Gillespie K, Hortsch M, Isom LL (2000) Sodium channel b subunits mediate homophilic cell adhesion and recruit ankyrin to points of cell-cell contact. J Biol Chem 275:11383-11388.

Malhotra JD, Thyagarajan V, Chen C, Isom LL (2004) Tyrosinephosphorylated and nonphosphorylated sodium channel betal subunits are differentially localized in cardiac myocytes. J Biol Chem 279:40748-40754.

Mantegazza M, Cestèle S (2005) $\beta$-Scorpion toxin effects suggest electrostatic interactions in domain II of voltage-dependent sodium channels. J Physiol 568:13-30.

McEwen DP, Meadows LS, Chen C, Thyagarajan V, Isom LL (2004) Sodium channel b1 subunit-mediated modulation of Nav1.2 currents and cell surface density is dependent on interactions with contactin and ankyrin. J Biol Chem 279:16044-16049.

Meadows LS, Malhotra J, Loukas A, Thyagarajan V, Kazen-Gillespie KA, Koopman MC, Kriegler S, Isom LL, Ragsdale DS (2002) Functional and biochemical analysis of a sodium channel b1 subunit mutation responsible for generalized epilepsy with febrile seizures plus type 1. J Neurosci 22:10699-10709.

Meisler MH, Kearney JA (2005) Sodium channel mutations in epilepsy and other neurological disorders. J Clin Invest 115:2010-2017.

Morimoto M, Mazaki E, Nishimura A, Chiyonobu T, Sawai Y, Murakami A, Nakamura K, Inoue I, Ogiwara I, Sugimoto T, Yamakawa K (2006) SCN1A mutation mosaicism in a family with severe myoclonic epilepsy in infancy. Epilepsia 47:1732-1736.
Ogiwara I, Miyamoto H, Morita N, Atapour N, Mazaki E, Inoue I, Takeuchi T, Itohara S, Yanagawa Y, Obata K, Furuichi T, Hensch TK, Yamakawa K (2007) $\mathrm{Na}_{\mathrm{v}} 1.1$ localizes to axons of parvalbumin-positive inhibitory interneurons: a circuit basis for epileptic seizures in mice carrying an Scn1a gene mutation. J Neurosci 27:5903-5914.

Oguni H, Hayashi K, Osawa M, Awaya Y, Fukuyama Y, Fukuma G, Hirose S, Mitsudome A, Kaneko S (2005) Severe myoclonic epilepsy in infancy: clinical analysis and relation to SCN1A mutations in a Japanese cohort. Adv Neurol 95:103-117.

Oyama F, Miyazaki H, Sakamoto N, Becquet C, Machida Y, Kaneko K, Uchikawa C, Suzuki T, Kurosawa M, Ikeda T, Tamaoka A, Sakurai T, Nukina N (2006) Sodium channel beta4 subunit: down-regulation and possible involvement in neuritic degeneration in Huntington's disease transgenic mice. J Neurochem 98:518-529.

Patton DE, Goldin AL (1991) A voltage-dependent gating transition induces use-dependent block by tetrodotoxin of rat IIA sodium channels expressed in Xenopus oocytes. Neuron 7:637-647.

Qin N, D'Andrea MR, Lubin ML, Shafaee N, Codd EE, Correa AM (2003) Molecular cloning and functional expression of the human sodium channel beta1B subunit, a novel splicing variant of the betal subunit. Eur J Biochem 270:4762-4770.

Racine RJ (1972) Modification of seizure activity by electrical stimulation. II. Motor seizure. Electroencephalogr Clin Neurophysiol 32:281-294.

Rusconi R, Scalmani P, Cassulini RR, Giunti G, Gambardella A, Franceschetti S, Annesi G, Wanke E, Mantegazza M (2007) Modulatory proteins can rescue a trafficking defective epileptogenic $\mathrm{Na}_{\mathrm{v}} 1.1 \mathrm{Na}^{+}$channel mutant. J Neurosci 27:11037-11046.

Scheffer IE, Harkin LA, Grinton BE, Dibbens LM, Turner SJ, Zielinski MA, Xu R, Jackson G, Adams J, Connellan M, Petrou S, Wellard RM, Briellmann RS, Wallace RH, Mulley JC, Berkovic SF (2007) Temporal lobe epilepsy and GEFS+ phenotypes associated with SCN1B mutations. Brain 130:100-109.

Sigel E, Minier F (2005) The Xenopus oocyte: system for the study of functional expression and modulation of proteins. Mol Nutr Food Res 49:228-234.

Smith RD, Goldin AL (1998) Functional analysis of the rat I sodium channel in Xenopus oocytes. J Neurosci 18:811-820.

Spampanato J, Kearney JA, de Haan G, McEwen DP, Escayg A, Aradi I, MacDonald BT, Levin SI, Soltesz I, Benna P, Montalenti E, Isom LL, Goldin AL, Meisler MH (2004) A novel epilepsy mutation in the sodium channel SCN1A identifies a cytoplasmic domain for beta subunit interaction. J Neurosci 24:10022-10034.

Tammaro P, Conti F, Moran O (2002) Modulation of sodium current in mammalian cells by an epilepsy-correlated beta 1-subunit mutation. Biochem Biophys Res Commun 291:1095-1101.

Turnbull J, Lohi H, Kearney JA, Rouleau GA, Delgado-Escueta AV, Meisler MH, Cossette P, Minassian BA (2005) Sacred disease secrets revealed: the genetics of human epilepsy. Hum Mol Genet 14 [Spec No 2]:2491-2500.

Valdivia CR, Nagatomo T, Makielski JC (2002) Late Na currents affected by alpha subunit isoform and beta1 subunit co-expression in HEK293 cells. J Mol Cell Cardiol 34:1029-1039.

Vanoye CG, Lossin C, Rhodes TH, George AL Jr (2006) Single-channel properties of human NaV1.1 and mechanism of channel dysfunction in SCN1A-associated epilepsy. J Gen Physiol 127:1-14.

Vu D, Di Sanza C, Neerman-Arbez M (2008) Manipulating the quality control pathway in transfected cells: low temperature allows rescue of secretion-defective fibrinogen mutants. Haematologica 93:224-231.

Wallace RH, Wang DW, Singh R, Scheffer IE, George AL Jr, Phillips HA, Saar K, Reis A, Johnson EW, Sutherland GR, Berkovic SF, Mulley JC (1998) Febrile seizures and generalized epilepsy associated with a mutation in the $\mathrm{Na}^{+}$-channel betal subunit gene SCN1B. Nat Genet 19:366-370.

Wallace RH, Marini C, Petrou S, Harkin LA, Bowser DN, Panchal RG, Williams DA, Sutherland GR, Mulley JC, Scheffer IE, Berkovic SF (2001a) Mutant GABA(A) receptor gamma2-subunit in childhood absence epilepsy and febrile seizures. Nat Genet 28:49-52.

Wallace RH, Scheffer IE, Barnett S, Richards M, Dibbens L, Desai RR, Lerman-Sagie T, Lev D, Mazarib A, Brand N, Ben-Zeev B, Goikhman I, Singh R, Kremmidiotis G, Gardner A, Sutherland GR, George AL Jr, Mulley JC, Berkovic SF (2001b) Neuronal sodium-channel alpha1- 
subunit mutations in generalized epilepsy with febrile seizures plus. Am J Hum Genet 68:859-865.

Wallace RH, Scheffer IE, Parasivam G, Barnett S, Wallace GB, Sutherland GR, Berkovic SF, Mulley JC (2002) Generalized epilepsy with febrile seizures plus: mutation of the sodium channel subunit SCN1B. Neurology 58:1426-1429.

Weckx S, Del-Favero J, Rademakers R, Claes L, Cruts M, De Jonghe P, Van Broeckhoven C, De Rijk P (2005) novoSNP, a novel computational tool for sequence variation discovery. Genome Res 15:436-442.

West JW, Patton DE, Scheuer T, Wang Y, Goldin AL, Catterall WA (1992) A cluster of hydrophobic amino acid residues required for fast $\mathrm{Na}(+)$ channel inactivation. Proc Natl Acad Sci U S A 89:10910-10914.

Witkin JM, Baez M, Yu J, Barton ME, Shannon HE (2007) Constitutive deletion of the serotonin-7 (5-HT(7)) receptor decreases electrical and chemical seizure thresholds. Epilepsy Res 75:39-45.

Wolff M, Casse-Perrot C, Dravet C (2006) Severe myoclonic epilepsy of infants (Dravet syndrome): natural history and neuropsychological findings. Epilepsia 47 [Suppl 2]:45-48.

Xu R, Thomas EA, Gazina EV, Richards KL, Quick M, Wallace RH, Harkin LA, Heron SE, Berkovic SF, Scheffer IE, Mulley JC, Petrou S (2007) Generalized epilepsy with febrile seizures plus-associated sodium channel beta1 subunit mutations severely reduce beta subunit-mediated modulation of sodium channel function. Neuroscience 148:164-174.

Yamakawa K (2005) Epilepsy and sodium channel gene mutations: gain or loss of function? Neuroreport 16:1-3.

Yilmaz I, Sezer Z, Kayir H, Uzbay TI (2007) Mirtazapine does not affect pentylenetetrazole- and maximal electroconvulsive shock-induced seizures in mice. Epilepsy Behav 11:1-5.

Yu FH, Mantegazza M, Westenbroek RE, Robbins CA, Kalume F, Burton KA, Spain WJ, McKnight GS, Scheuer T, Catterall WA (2006) Reduced sodium current in GABAergic interneurons in a mouse model of severe myoclonic epilepsy in infancy. Nat Neurosci 9:1142-1149. 